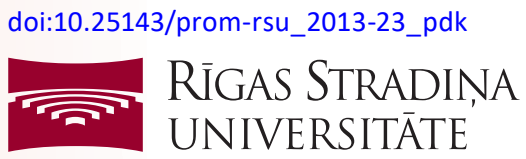

\title{
Iveta Briška
}

\section{EKOLOĢISKIE RISKI LATVIJAS IEDZIVOTĀJU VËRTËJUMĀ}

Promocijas darba kopsavilkums Specialitāte - socioloǵija 


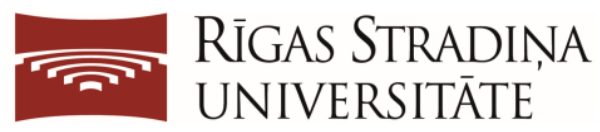

Iveta Briška

\section{EKOLOĢISKIE RISKI LATVIJAS IEDZĪVOTĀJU VĒRTĒJUMĀ}

Promocijas darba kopsavilkums

Specialitāte - socioloğija

Rīga, 2013 
Promocijas darbs izstrādāts Rīgas Stradiņa universitātē

Darba zinātniskā vadītāja:

Dr. sc. soc., asociētā profesore Ritma Rungule, Rīgas Stradiṇa universitāte

Oficiālie recenzenti:

Dr. phil. soc. darbā, asociētā profesore Signe Dobelniece,

Rīgas Stradiņa universitāte, Latvijas Lauksaimniecības universitāte

Dr. sc. soc., profesors Aivars Tabuns, Latvijas Universitāte

Dr. sc. pol., profesors Vladimirs Men̦šikovs, Daugavpils Universitāte

Promocijas darba aizstāvēšana notiks 2013. gada 18. septembrī plkst. 10.00 Rīgas Stradina universitātes Sociologijas promocijas padomes atklātā sēdē Rīgā, Dzirciema ielā 16, Hipokrāta auditorijā.

Ar promocijas darbu var iepazīties RSU bibliotēkā un RSU mājaslapā: www.rsu.lv

Promocijas darbs veikts ar Eiropas sociālā fonda projekta "Atbalsts doktorantiem studiju programmas apguvei un zinātniskā grāda ieguvei Rīgas Stradiņa universitātē" finansiālu atbalstu.
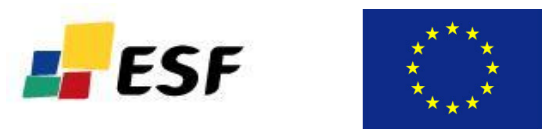

Promocijas padomes sekretāre:

Dr. phil. soc. darbā, asociētā profesore Signe Dobelniece 


\section{SATURS}

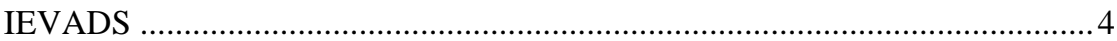

Pētījuma tēmas aktualitāte un praktiskā nozīme ............................................. 4

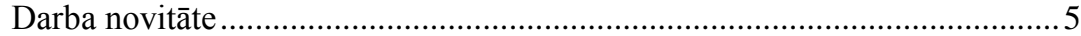

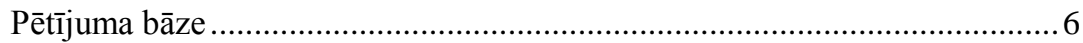

Darba teorētiskais ietvars un pamatjēdzieni ................................................. 7

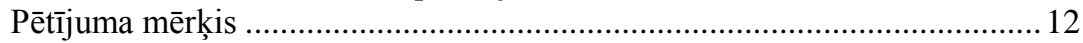

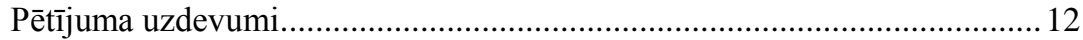

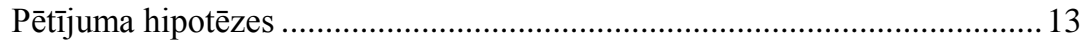

Pētījumā izmantotās metodes.................................................................... 13

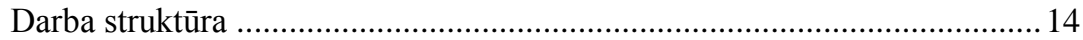

1. RISKA SABIEDRĪBAS TEORĒTISKAIS RAKSTUROJUMS .................15

1.1. Riska un riska sabiedrības koncepcija mūsdienu sociologijāā .................15

1.1.1. Riska konceptuālo pieeju raksturojums ..................................... 16

1.1.2. Niklasa Lūmana sociologiskā riska teorija .............................. 18

1.1.3. Entonija Gidensa pieeja riska interpretācijā ............................ 19

1.1.4. Ulrihs Beks: riska koncepcijas skaidrojums .............................20

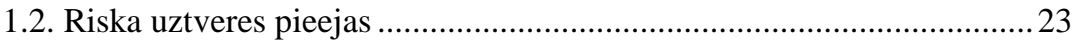

2. EKOLOĢISKO RISKU KONCEPCIJA UN IZPĒTE …...........................25

2.1. Ekoloǵiskie riski riska sabiedrības teorētiskajā koncepcijā ..................25

2.1.1. Dabas socializācija: ekologisko risku aizsākums .........................25

2.1.2. Ekoloǵisko risku aktualizēšana: „Jaunā ekolog̣iskā

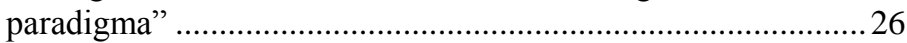

2.1.3. Ekologisko risku uztveres un izvērtēšanas modelis...................27

2.1.4. Ekolog̣iskā apziņa un ekologiskā uzvedība: uzskati un rīcība ..28

2.2.Pètījumi par ekologijas problemātiku Latvijā ........................................ 30

3. IEDZĪVOTĀJU VĒRTĒJUMS PAR RISKA SABIEDRĪBU UN

EKOLOĢISKAJIEM RISKIEM LATVIJĀ ..................................................... 34

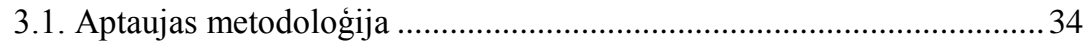

3.2. Iedzīvotāju attieksme pret vides aizsardzību Latvijas problēmu

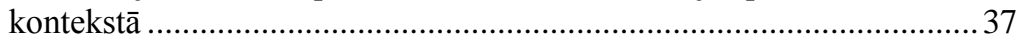

3.3. Ekologiisko risku identificēšana un novērtējums....................................39

3.4. Iedzīvotāju viedoklis par riska sabiedrību............................................41

3.5. Latvijas iedzīvotāju informētība par ekoloǵiskajiem riskiem ................43

3.6. Latvijas iedzīvotāju gatavība darboties ekologisko risku

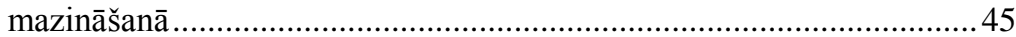

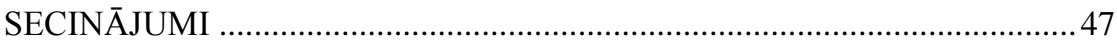

ZINĀTNISKIE RAKSTI PAR PROMOCIJAS DARBA TËMU .....................54

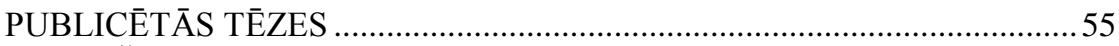

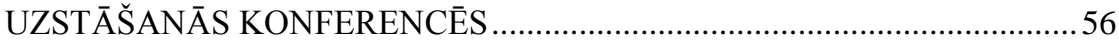

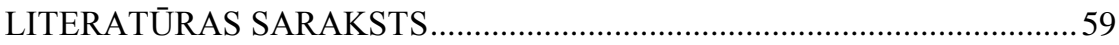




\section{IEVADS}

\section{Pētījuma tēmas aktualitāte un praktiskā nozīme}

Šā brī̌za sabiedrības attīstības procesi daudzu sociālo zinātņu teorētiķu skatījumā tiek apzīmēti ar jēdzienu ,riska sabiedrība”. Lai gan jēdziena aprises joprojām ir nenoteiktas un diskutējamas, pētījumi par dažādiem riska sabiedrības aspektiem un riska problemātiku kopumā ir viena no aktuālajām tēmām sociālajās zinātnēs kopumā. Tas nepārsteidz, jo risku apzināšanās, to analīze un novērtējums, kā arī izvairīšanās no riskiem vai vismaz to attālināšana ir vitāli svarīga cilvēcei kopumā un arī katram indivīdam atsevišķi.

Viens no risku veidiem, kurus ǵenerē pati riska sabiedrības pretrunīgā attīstība, ir ekologiskie riski, un tie ir l̦oti daudzveidīgi. Tie paši instrumenti, kurus radījusi sabiedrība dzīves uzlabošanai un kuri ilgu laiku asociējās ar progresu, tagad ir izvērtušies savā pretstatā. Lielu apmēru ekologiiskās katastrofas, ko izraisa gan dabas procesi, gan cilvēku darbība, ir šā gadsimta raksturīgākie draudi.

Ir jārēķinās, ka, dzīvojot industriālā vidē, iedzīvotājiem ieguvumu vārdā nākas sadzīvot ar potenciāliem riskiem, un cilvēkiem ir arī jāapzinās, ka gandrīz ikviens vinuu dzīves aspekts ietekmē vidi. Jebkura rīcība var nākotnē izraisīt ekologiskas problēmas (Beck, 1991).

Tomēr jebkura rīcība vai notikums izraisa arī pretreakciju. Atbildes reakcija uz industriālās pasaules krīzi un pieaugošām ekolog̣iskām kataklizmām, kas raksturīgas riska sabiedrībai, ir ekoloǵiskā apziņa - pārmaiṇas ekoloǵiskajā apziņā (O’Sullivan \& Taylor, 2004: 10-13).

Pastāv daudz objektīvu faktoru, kas liecina par ekoloǵisko risku pieaugumu, taču tam neseko atbilstoša iedzīvotāju reakcija - ekoloǵiskās apziņas izpausme - šo risku mazināšanā. Tas liek pievērsties Latvijas iedzīvotāju ekolog̣iskās apziņas komponentu satura analīzei, to savstarpējo sakarību un ietekmējošo faktoru izpētei. 
Autore promocijas darba ietvaros vēlas noskaidrot, vai Latvijas iedzīvotāji, dzīvojot konkrētā vidē, apzinās iespējamos riskus un saskata dažādos tautsaimniecības un vispārējā progresa virzošajos procesos ekologisko risku potenci, vai ir gatavi ieguldīt laiku un līdzekḷus vides uzturēšanā un aizsardzībā, kā arī to, vai aktīvi lieto zināšanas par ekoloǵiskajiem riskiem. Veikusi šādu analīzi, autore varēs sniegt Latvijas iedzīvotāju ekologiskās apziṇas raksturojošo komponentu satura vērtējumu, atsegt šo komponentu savstarpējo sakarību un tos ietekmējošos faktorus. Savukārt pilnīgāks priekšstats par ekoloǵiskās apziņas līmeni un saturu l̦aus efektīvāk darboties risku pārvaldībā.

Promocijas darbam ir praktiska nozīme. Tas izmantojams kā teorētisks un metodologisks materiāls akadēmiskā kursa "Riska sabiedrība" izstrādei, un tā vērtību vairo plašais apkopotais materiāls par ekologisko risku problemātiku, kas attiecas uz Latviju un ir uzkrāts ilgstošā periodā.

\section{Darba novitāte}

Līdz šim Latvija ir piedalījusies dažādos starptautiskos pētījumos, kas saistīti ar vides jautājumiem. Ir bijuši atsevišķi vietēja mēroga pētījumi par ekoloǵiskām problēmām valstī. Šā pētījuma centrā ir ekoloǵisko problēmu analīze, uzsverot ekologisko risku specifiku. Promocijas darba ietvaros veiktais pētījums sniedz ieguldījumu riska sabiedrības teorētiskās pieejas, empīrisko pētījumu attīstībā Latvijā, kā arī Latvijas iedzīvotāju ekologiiskās apziṇas analīzē, iezīmējot riska sabiedrības un ekoloǵisko risku pētniecības tematiku:

- promocijas darba teorētiskajā dal̦ā veikta plaša jēdzienu "risks" un "riska sabiedrība" sociolog̣iska analīze;

- veikta riska sabiedrības socioloǵijas teorētiskās paradigmas analīze, fokusējot uzmanību uz ekologisko risku izpausmēm; 
- tematiski analizēti un sistematizēti līdz šim veiktie empīriskie pētījumi par ekologiskajiem riskiem un vides problemātiku Latvijā kopumā;

- empīriskā pētījuma novitāte attiecas uz Latvijas iedzīvotāju ekologiskās apziņas novērtējumu, pamatojoties uz apkārtējās vides problemātikas analīzi.

\section{Pētījuma bāze}

Lai noskaidrotu iedzīvotāju viedokli par apkārtējās vides problēmām un ekologiiskiem riskiem, ko izraisa šīs problēmas, kā arī iesaistīšanos aktivitātēs apkārtējās vides aizsardzības jomā, bija nepieciešams veikt virkni iedzīvotāju attieksmju mērījumu - noskaidrot personiskās attieksmes, zināšanu pašnovērtējumu, gatavību iesaistīties apkārtējās vides aizsardzības aktivitātēs utt. Šim nolūkam promocijas darba trešajā nodaḷā kā informācijas ieguves veids tika izmantota intervēšana un izveidots pêtījuma instruments - daļēji standartizēta anketa (sk. promocijas darba 1. pielikumu).

Anketa tika sagatavota latviski un tulkota krieviski, ņemot vērā Latvijas iedzīvotāju etnisko sastāvu. Pētījuma izlase tika veidota tā, lai aptaujā tiktu ietvertas dažādas sociāldemogrāfiskās grupas. Aprēķinot izlasi, tika ņemti vērā pieci demogrāfiskie rādītāji: dzimums; vecums, tautība, reǵionālais sadalījums un sadalījums pēc apdzīvotās vietas tipa.

Kvantitatīvais pêtījums tika veikts visas Latvijas teritorijā: Rīgā, Pierīgā, Kurzemē, Zemgalē, Vidzemē un Latgalē. Lai aptaujā iegūtu datus, kas reprezentē mērķa grupas viedokļus, tika veidota generālajam kopumam (Latvijas iedzīvotāji) reprezentatīva izlase, pamatojoties uz statistikas datiem par Latvijas iedzīvotāju skaitu. Statistikas dati par pētījuma generālo kopumu iegūti no Latvijas Republikas Iekšlietu ministrijas Pilsonības un migrācijas lietu 
pārvaldes Iedzīvotāju reǵistra. ${ }^{1}$ Tika veikts aprēķins, lai noteiktu izlases apjomu ar statistisko kḷūdu 3,5\% robežās. Atbilstoši šīm prasībām, pastāvot ǵenerālā kopuma apjomam 1679 691, aprēķinātais izlases apjoms ir n=800. Reālais izlases apjoms bija $\mathrm{n}=813$.

Atbilstoši pētījuma mērķim un uzdevumiem tika noteiktas aptaujas generālkopas vecuma grupu robežas - sākot no 18 gadiem un beidzot ar 74 gadiem ieskaitot. Aptauja tika veikta, izmantojot telefonintervijas, un ar vienu personu, kura atbildēja uz intervētāja veikto zvanu.

\section{Darba teorētiskais ietvars un pamatjēdzieni}

Līdzịi kā 19. gadsimtā modernizācijas (tā ietver sarežğìtu procesu kompleksu, kas skar ekonomikas, politikas, sociālo un kultūras jomu) ietekmē feodālismu nomainīja industriālā sabiedrība, tāpat mūsdienās industriālā sabiedrība ir pārtapusi riska sabiedrībā (Giddens, 1994). Gan Ulrihs Beks (Ulrich Beck), gan Entonijs Gidenss (Anthony Giddens) - divi redzamākie mūsdienu sociālās domas paudēji - uzskata, ka industriālajai modernitātei raksturīgo bagātību radīšanas ideju ir aizēnojusi risku novēršanas ideja, sociālo šķiru apzināšanos ir nomainījusi risku apzināšanās, bet paaugstināta dzīves riska vidē izpratne par norisēm ir kḷuvusi par galveno sociālās transformācijas katalizatoru. Citiem vārdiem, teorētiķi apgalvo, ka ir nepieciešamas sociālas, politiskas un institucionālas reformas, lai atvieglotu pāreju no industriālas modernitātes (kas bija centrēta uz materiālo labumu ražošanu) uz refleksīvo modernitāti (kas fokusējas uz zināšanu ražošanu, risku novēršanu un dabas saglabāšanu) (Ekberg, 2007: 347). Industriālajai sabiedrībai pārtopot par riska sabiedrību, tiek aktualizēts un konceptualizēts jēdziens "risks". 20. gadsimta 90. gados U. Beks paziņoja, ka globalizācijas procesa gaitā industriālā

\footnotetext{
${ }^{1}$ LR IeM PMLP Iedzīvotāju reǵistra dati 2011.7.IX (pētījumu centrs SKDS)
} 
sabiedrība pārtop globālā risku sabiedrībā. Viņš uzskatīja, ka riska sabiedrības problēmas neaprobežojas tikai ar apdraudējumiem, kas saistīti ar apkārtējās vides piesārṇošanu. Riska sabiedrībai ir raksturīga pilnīga laika, teritoriālo un sociālo robežu izzušana (Beck, 1992b: 136). Termins "riska sabiedrība" tika ieviests 20. gadsimta 80. gadu beigās, lai raksturotu modernizācijas un cilvēka darbības apdraudēto sabiedrību un to, kā sabiedrība reaǵē uz šiem riskiem. Termins asociējas galvenokārt ar vācu sociologa U. Beka un angḷu sociologa E. Gidensa darbiem. Kā uzskata U. Beks, pēdējos gados pasaule dzīvo riska sabiedrībā, šajā laikmetā mazākais iespējamais cēlonis izraisa lielāko iespējamo postu. U. Beks arī norāda, ka mūsdienu pasaulē materiālo labumu sabiedriskā ražošana ir cieši saistīta ar risku ražošanu. Problēmas un konflikti šādā sabiedrībā pārklājas ar problēmām un konfliktiem, kas izriet no zinātniski un tehnoloğiski radīto risku pārprodukcijas, identificēšanas un sadales (Beck, 1992a: 122).

Riska sabiedrība, tāpat kā industriālā sabiedrība, nav ilgtspējīga. U. Beks uzskata, ka tā apdraud dabas resursu saglabāšanas iespējas, pārāk ātri tos izsmeḷot un neḷaujot tiem atjaunoties, bet atkritumi un piesārņojumi, kas rodas rūpnieciskās ražošanas rezultātā, kaitē apkārtējai videi un kavē tās atjaunošanos (Beck, 1999: 102).

Situācijā, kad sabiedrība ir pakḷauta daudziem apzinātiem un neapzinātiem riskiem un ir spiesta rast risinājumus dažādiem draudiem un mazināt attīstības un progresa negatīvo aspektu ietekmi uz cilvēku dz̄ivi un apkārtējo vidi, noteikt ekoloǵisko risku avotus nav viegli (Giddens, 1996: 86). Tomēr jāatzīmē, ka pareiza, līdzsvarota sociālo, politisko un ekonomisko komponentu kombinācija var dot iespēju aizsargāt apkārtējo vidi no briesmām un būtiski uzlabot ekologisko situāciju kopumā.

U. Beka riska sabiedrības koncepcija balstās uz jaunas "riska apziṇas" veidošanos tehnisko un sociālo pārmaiņu ietekmē un kontekstā (Wilkinson, 2001b: 2). Var paredzēt, ka ekoloǵiskie riski un veselības riski, ko rada 
tehnologijas, kā arī jaunu ražošanas metožu ieviešana rūpniecībā un lauksaimniecībā, piemēram, plaša pesticīdu lietošana, dominēs riska sabiedrības sabiedriskajā diskursā (Block, 2008: 757). Vispārpieejamās zināšanas dažādos veidos savijas ar zinātniskās kompetences problēmām (Lidskog, 1996: 31). Tāpēc līdzās riska regulēšanas metožu izstrādei ir nepieciešams analizēt arī to, kā sabiedrība iesaistās zināšanu veidošanas aktīvajās formās. Šāda nenoteiktība un satraukumi ir saistīit ne tikai ar īpaši bīstamajiem riskiem - lai minam Černobiḷas avāriju -, bet arī ar lokālajām problēmām, piemēram, droša dzeramā ūdens nodrošināšanu no ūdens krāna (Mol, 1993: 431).

Lai dziḷāk izzinātu riska mainīgo raksturu un dažādas attieksmes pret risku riska sabiedrībā, U. Beks un E. Gidenss ir pētījuši pārmaiņas ekoloǵisko un ekonomisko risku cēloṇu un seku izpratnē. Šīs transformācijas ietver uzsvara novirzi no riskiem, kas saistīti ar dabu, uz riskiem, kas saistīti ar tehniku un tehnologiju; novirzi no reālistiskās pieejas riskam uz sociālā konstruktīvisma pieeju; pieaugošo plaisu starp faktisko un paredzamo risku, kā arī pārmaiṇas risku sadalē (Beck, 1992b).

N̦emot vērā minēto riska un riska sabiedrības piemēru traktējumu, nav šaubu, ka globalizācijas laikmetā arī Latvija saskaras ar tādām sabiedrības kvalitātēm un attīstības tendencēm, uz kurām attiecināms jēdziens "riska sabiedrība". Promocijas darba teorētisko pamatojumu veido trīs nozīmīgāko riska sabiedrības teorētiķu - U. Beka, E. Gidensa un N. Lūmana - teorētiskās pieejas. Svarīgi atzīmēt, ka runa ir nevis par trim dažādām pieejām, bet gan par trim riska sabiedrības traktēšanas model̦iem, jo ir konstatējamas vairākas kopīgas pazīmes, kas caurvij minēto trīs sociologu darbus riska un riska sabiedrības analīzē. Lai sasniegtu promocijas darba mērķi, proti, izpētītu sabiedrības ekoloǵiskās apziņas raksturojošo pazīmju saturu un savstarpējās saistība, darba konceptuālā uzbūve ir organizēta tādējādi, ka katram ekoloǵiskās apziņas komponentam atbilst kāds no kvantitatīvā pētījuma 
moduḷiem. Promocijas darba konceptuālā uzbūve ir atspoguḷota 1. attēlā. Tātad ekologiskās apziņas trīs komponentu - norūpētības, gatavības rīcībai un zināšanu - saturs atbilstoši tiek interpretēts, analizējot Latvijas iedzīvotāju viedokli par ekoloǵisko risku vērtējumu, informētību par ekologiiskajiem riskiem un aktivitātes risku mazināšanai.

Promocijas darbā izmantoti un turpmākajās nodal̦ās izvērsti analizēti četri pamatjēezzieni. Turpinājumā sniegtas to definīcijas.

Risks (anglu val. risks, hazard, danger) - ir rezultāts jeb galaprodukts, ko ik dienu ražo mūsu lēmumu pieņemšana, ko rada lēmumu sekas. Būtiski atzīmēt, ka darbā, turpmāk lietojot jēdzienu „risks”, ekvivalenti līdzvērtīgi tiks lietoti arī jēdzieni „briesmas”, „draudi” un „bīstamība”. Teorētiskajā literatūrā, piemēram, N. Rešers (Nicholas Rescher) nošķir šos jēdzienus, savukārt E. Gidenss ir pielīdzinājis tos vienai nozīmei, pamatojot to tā, ka risku var traktēt arī kā nākotnes kaitējuma bīstamību. Šādas jēdzienu pielīdzināšanas nepieciešamību apstiprināja arī promocijas darba kvantitatīvā pētījuma pilotaptauja, kuras gaitā respondenti atbildēja rezultatīvāk, ja jautājumos tika lietoti gan jēdziens "risks”, gan arī jēedzieni „briesmas”, „draudi”, „bīstamība” (Giddens, 1991; Beck, 1992b, 1995; Rescher, 1983; Luhmann, 1994).

Riska sabiedrība (angḷu val. risk society) - ir industriālās sabiedrības attīstības rezultāts, attīstības process, kurā sabiedrība pastāvīgi generē riskus, kas ir neparedzami un vispārēji, tādējādi riska sabiedrībā jebkuras darbības ir jâvērtē no riska iespējamības pię̧āvuma (Beck, 1992b; Luhmann, 1994).

Ekologiiskā apziṇa (angḷu val. ecological awareness) - apzināšanās, ka gandrīz ikviens cilvēku dzīves aspekts ietekmē vidi, un šo fenomenu raksturo, izvērtējot iedzīvotāju norūpētību jeb satraukumu par vides degradāciju, viṇu gatavību ziedot laiku un ieguldīit līdzekḷus vides uzturēšanā un uzlabošanā; zināšanas par vidi degradējošiem faktoriem un to novēršanu (Kalniņa \& Meņšikovs, 2003; Christopher, 1999; Leff, 1978; Sanchez \& Lafuante, 2010; O’Sullivan \& Taylor, 2004; Uhl, 2003). 


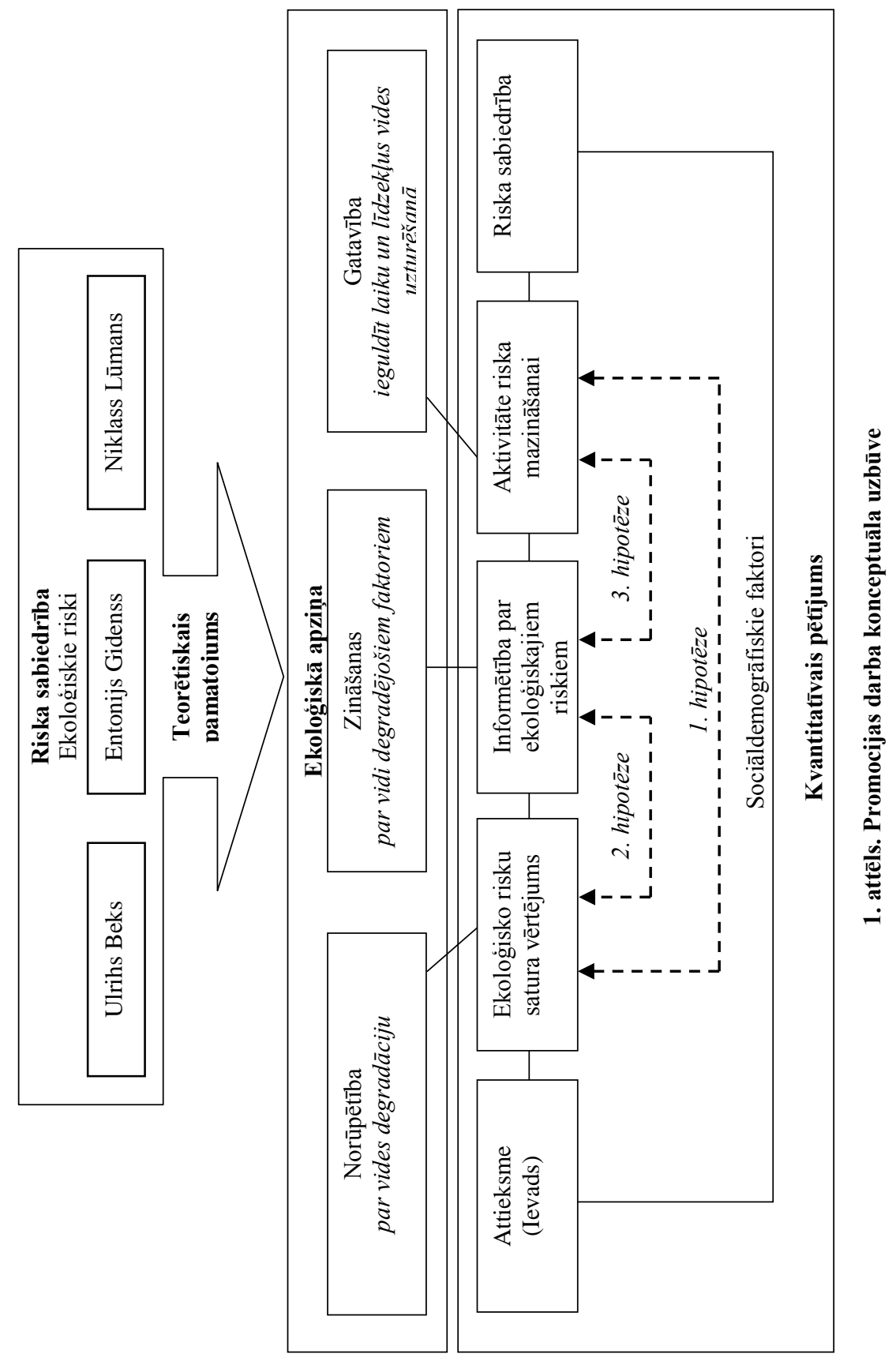


Ekoloğiskie riski (angḷu val. ecological risks) - riski, kādus sabiedrībai, indivīdam un dabai rada ekoloǵisko faktoru kopums; šie riski ir saistîti ar apkārtējās vides piesārņošanu cilvēka apzinātas darbības, kā arī neinformētas, nezinīgas (zināšanu trūkuma radītas) rīcības rezultātā. Tie ir apkārtējai videi nodarītā kaitējuma sekas, kas apdraud cilvēku darba, sadzīves, atpūtas apstākḷus un veselību, jūtami ietekmē viṇu dzīves kvalitāti (Beck, 1995b; Giddens, 1990).

\section{Pētījuma mērķis}

Promocijas darba mērḳis ir veikt Latvijas sabiedrības ekologiskās apziņas izpēti, pamatojoties uz Latvijas iedzīvotāju priekšstatiem par ekologiisko risku vērtējumu.

\section{Pētījuma uzdevumi}

1. Kompleksi analizēt pētījumā izmantotos pamatjēdzienus: risks, riska sabiedrība, ekologiskais risks, ekologiskā apzinga un ar tiem asociētos jēdzienus (ekologiskā norūpētība u.c.), analizēt un sistematizēt riska uztveres teorijas.

2. Izpētìt, apkopot un analizēt riska sabiedrības teorētiskos aspektus un pazīmes.

3. Apzināt un sistematizēt 20. gadsimta beigās - 21. gadsimta sākumā veiktos pētījumus vides problēmu un ekoloǵisko risku jomā Latvijā un sniegt to tematisku analīzi.

4. Novērtēt ekoloǵiskos riskus, kas nosaka Latvijas iedzīvotāju norūpētību par vides degradāciju

5. Izmantojot aptauju, noskaidrot un novērtēt iedzīvotāju informētības līmeni, analizēt tā lomu ekologisko risku apzināšanās procesā. 
6. Noskaidrot un analizēt Latvijas iedzīvotāju gatavību darbībām, lai mazinātu jaunu ekologisko risku rašanos un esošo pastiprināšanos.

\section{Pētijuma hipotēzes}

1. Latvijas iedzīvotāju ekologisko risku satura vērtējumam ir vāja savstarpēja saistība ar Latvijas iedzīvotāju aktivitāti risku mazināšanā;

2. Latvijas iedzīvotāju informētībai par ekoloǵiskajiem riskiem ir vāja savstarpēja saistība ar ekologisko risku satura vērtējumu;

3. Latvijas iedzīvotāju informētībai par ekoloǵiskajiem riskiem ir vāja savstarpēja saistība ar Latvijas iedzīvotāju aktivitāti risku mazināšanā.

Pētījuma hipotēzes ir izvirzìtas, pamatojoties uz pieņēmumiem par ekoloǵiskās apziņas komponentu savstarpējo sakarību un ietekmi. Hipotēžu grafisko attēlojumu sk. 1. attēlā.

\section{Pētījumā izmantotās metodes}

Dokumentu analīze (literatūras un iepriekš veikto kvantitatīvo aptauju studijas un analīze); aptauja, izmantojot dal̦ēji strukturētu anketu. Aptauja tika veikta, izmantojot telefonintervijas. Pētnieciskie jautājumi tika analizēti, lietojot deskriptīvo analīzi, korelācijas analīzi, standartizēto atlikumu analīzi, Pīrsona $\chi^{2}$ testu, rangu korelācijas koeficientus (Kendall's tau b, Goodman un Kruskal tau koeficenti), kā arī saistību un statistiski būtisku likumsakarību modelēšanu, izmantojot loglineārās analīzes logit analīzes (logit analysis) modeli un modeļa izvēles (model selection) analīzes veidu. (Крыштановский, 2006; Аптон, 1982, Acton \& Miller, 2009). ${ }^{2}$

\footnotetext{
${ }^{2}$ Visu metožu izklāstu un terminu skaidrojumu sk. promocijas darba 3. nodaḷā.
} 


\section{Darba struktūra}

Promocijas darbu veido ievads, trīs nodạ̧as, secinājumi, literatūras saraksts un astoņi pielikumi.

Ievadā ir pamatota tēmas aktualitāte, definēti promocijas darbā izmantotie pamatjēdzieni, izklāstīts darba teorētiskais pamatojums, definēts pētījuma objekts un priekšmets, noformulēti darba mērḳi un uzdevumi.

Pirmā nodạ̣a ir strukturēta divās apakšnodaḷās. Pirmā apakšnodaḷa ir veltīta riska un riska sabiedrības teorētiskās paradigmas analīzei. Aplūkotas Niklasa Lūmana, Entonija Gidensa un Ulriha Beka teorētiskās pieejas riska un riska sabiedrības problemātikas risinājumiem. Otrajā apakšnodaḷā ir analizētas dažādas riska uztveres teorijas.

Otro nodaḷu veido divas apakšnodaļas. Pirmajā ir aplūkots risku iedalījums un risku analīzes pamatnostādnes, kā arī sniegts ekoloǵisko risku analīzes teorētisks pamatojums empīriskajā dal̦ā. Otrajā apakšnodaļā analizēti dažādi līdz šim Latvijā veiktie pētījumi, kuru uzmanības centrā bijusi apkārtējās vides, vides aizsardzības, ekoloǵiskos riskus ǵenerējošu sociālo procesu, kā arī pašu ekologisko risku problemātika Latvijā.

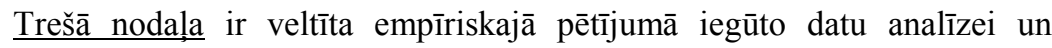
interpretācijai. Tā sastāv no sešām apakšnodaḷām.

Pirmajā apakšnodaļā ir raksturota pētījuma metodoloğija, ietverot pētījuma instrumentāriju, aptaujas metodi, izlases raksturojumu, nerespondences raksturojumu, statistiskās kḷūdas novērtēšanas sistēmu, kā arī datu ieguvi un apstrādi. Šajā apakšnodaḷā sniegts arī izlases sociāldemogrāfiskais raksturojums.

Otrajā apakšnodaḷa uzmanība pievērsta vispārējam iedzīvotāju viedoklim par vidi un citām Latvijā identificētajām riska problēmām. Trešajā apakšnodaļā identificēti Latvijas ekoloǵiskie riski, sniegts ekoloǵisko risku un 
ekoloǵiskos riskus izraisošo dzīvības procesu indikatoru novērtējums. Ceturtajā apakšnodalāa interpretēti dati par riska sabiedrības pazīmju novērtēšanu iedzīvotāju skatījumā, bet piektajā apakšnodaļā analizēts Latvijas iedzīvotāju informētības līmenis par vides problēmām, ekoloǵiskajiem riskiem un dzīvības procesiem, kas izraisa ekoloǵiskos riskus. Sestajā apakšnodaḷā analizēta Latvijas iedzīvotāju uzvedība, lai mazinātu negatīvo seku iedarbību uz cilvēku un apkārtējo vidi.

Secinājumos sniegts rezumējums pētījuma gaitā iegūtajai informācijai.

Promocijas darba apjoms ir 160 lappuses. Darba saturs veidots uz 170 bibliogrāfisko avotu bāzes. Teorētiski analītisko materiālu papildina astoṇi pielikumi.

\section{RISKA SABIEDRĪBAS TEORĒTISKAIS RAKSTUROJUMS}

\subsection{Riska un riska sabiedrības koncepcija mūsdienu socioloğijā}

Lai gan termins riska sabiedrība asociējas galvenokārt ar pazīstamo sociālo teorētiķu U. Beka un E. Gidensa darbiem, tomēr riska sabiedrības ideja attīstīta arī citu sociologu, sociālo un kultūras antropologu, ekonomistu, fiziķu un citu zinātnes nozaru pārstāvju darbos.

Riska sabiedrībā pastāv daudzi apzināti un neapzināti tehnologiskas un sociālas izcelsmes riski: globālā sasilšana, vides piesārṇošana industriālo objektu darbības un šo objektu avāriju rezultātā, toksisko ķīmisko vielu izmantošana, bīstamo atkritumu apsaimniekošana u.c. Risku ražošana notiek visās sabiedrisko procesu norises jomās: ekonomiskajā, politiskajā un sociālajā vidē. Ir nepieciešami daudzveidīgi un efektīvi risinājumi, kas varētu nodrošināt risku adekvātu pārvaldīšanu. Tāpēc sabiedrībai rodas nepieciešamība izvērtēt 
un aprēķināt pašas radītos riskus, piemēram, tehnisku/tehnologiisku avāriju un katastrofu varbūtības noteikšana ir ļoti svarīga dažādu tehnisko/tehnoloǵisko sistēmu vadības nodrošināšanai.

Riska sabiedrības izziṇa interesē daudzas zinātnes nozares, un tas dod pienesumu gan riska sabiedrības izpratnē, gan arī l̦auj attīstīt jaunus pētījumu virzienus, turklāt dažādās pieejas ļauj precīzāk definēt situāciju un lemt par risku praktisku vadīšanu. Riska izpētes specifiku nosaka konkrētās zinātnes pētījuma priekšmets, dažādas zinātniskās pieejas un metodes. Sava pieeja ir arī socioloǵijai, un šis promocijas darbs veltīts noteiktu tās aspektu analīzei riska problemātikas kontekstā.

\subsubsection{Riska konceptuālo pieeju raksturojums}

Risks tiek traktēts kā „sabiedrības sistemātiska mijiedarbība ar draudiem un briesmām, ko rada modernizācijas process” (Beck, 1992b: 45).

Jau kopš seniem laikiem valsts varas iestādes tiešā veidā ir centušās mazināt, novērst un kontrolēt riskus, arī viena no valdības funkcijām izsenis ir saistīta ar iedzīvotāju aizsargāšanu pret tām briesmām, pret kurām viņi paši nespēj sevi aizsargāt (sk. TeBrake, 1975; Covello, 1985: 41; Grier, 1981: 3; Hägerstrand, 1985: 13; Hammer, 1980: 23; Handler, 1979; Kunreuther, 1973: 12; Pfeffer \& Klock, 1974: 215).

Socioloǵijā pastāv divi plaši riska kā sociāla fenomena interpretācijas virzieni - reālistiskais un sociokulturālais. Reālistiskās pieejas ietvaros risks tiek interpretēts zinātniskos un tehniskos terminos. Risks tiek traktēts kā objektīvs un izzināms fakts (potenciālā bīstamība vai jau nodarītais kaitējums), kas var tikt izmērīts neatkarīgi no sociālajiem procesiem un kultūras vides. Sociokulturālais riska analīzes virziens akcentē sociālo un kultūras kontekstu, kuru ietvaros risks tiek uztverts un iztirzāts. 
Riska sociologiijas vēsturnieki sociokulturālajā virzienā nosacīti nošķir trīs pieejas - (1) kultūrsimbolisko, kuru attīstīja britu antropoloǵe M. Duglasa (Mary Douglas) un viņas kolēgi, (2) riska sabiedrības teoriju, kuru pārstāv U. Beks un E. Gidenss, un (3) mūsdienu „kalkulatīvo racionalitāti”, kas balstās uz M. Fuko (Michel Foucault) darbiem. Pirmā pieeja fokusējas uz „personības” un „cita” savstarpējo attiecību problēmām, izrādot īpašu interesi par to, kā cilvēka ķermenis simboliski un metaforiski tiek izmantots diskursā un praksē saistībā ar riska problēmu. Otrā pieeja koncentrējas uz makrosociālajām pārmaiņām, ko rada riska ražošana vēlās modernitātes posmā. Tie ir refleksīvās modernizācijas/modernitātes procesi, iepriekšējā modernitātes un individuālisma posma seku kritika, tradicionālo vērtību un normu sagraušanas sekas. Trešās pieejas piekritējus maz interesē, ,kas īstenībā ir risks”, jo vinịi uzskata, ka „patiesību par risku” konstruē cilvēku diskurss, stratēgijas, prakses un institūcijas. Viṇi pēta to, kā dažādas riska koncepcijas rada specifiskas uzvedības normas, kuras var tikt izmantotas indivīdu motivēšanai brīvi piedalīties pašorganizēšanās procesos riskradošās situācijās (Lupton, 1999: 25, cit. no: Яницкий, 2001: 2).

Tāpat ir jānošķir riskoloǵisko pētījumu līnijas - mērenā un radikālā. Mērenās līnijas piekritēji uzskata, ka risks ir objektīvi pastāvoša bīstamība, ko vienmēr pastarpina sociālie un kultūras stereotipi un procesi. Radikālās līnijas pārstāvji apgalvo, ka pastāv nevis risks, bet riska uztvere, kas vienmēr ir vēsturiski, politiski un sociāli nosacītas pasaules uztveres produkts (Яницкий, 2001: 2).

Simt gadu laikā sociologija ir nogājusi garu ceḷu no daudzu atsevišķu risku un riskam pakḷautu situāciju pētniecības līdz izpratnei, ka pati sabiedrība ir risku ǵenerators. 80. gadu vidū risku pētǐšana kḷuva arvien sarežğîtāka un haotiskāka: risku analīzei acīmredzami trūka centrālā fokusa (Short, 1984: 711, cit. no: Яницкий, 2001: 4). Pasaulē atzītais krievu sociologs O. Jaņickis (Олег Яниџкий) uzskata, ka bija nepieciešama zināma visaptveroša koncepcija, kas 
pētītu un interpretētu riskus un riska sabiedrību. 20. gadsimta divos pēdējos gadu desmitos šādas visaptverošas koncepcijas izveidoja Niklass Lūmans, Entonijs Gidenss un Ulrihs Beks (Яницкий, 2003).

\subsubsection{Niklasa Lūmana socioloǵiskā riska teorija}

Vācu sociologa Niklasa Lūmana (Niklas Luhmann, 1927-1998) sociolog̣iskā riska teorija ir tieši saistīta ar mūsdienu sabiedrības racionalitātes kritiku. Viņš norāda, ka mūsdienu sabiedrības riska uzvedība vispār neiekḷaujas „racionālā/iracionālā shēmā”. Lūmans uzsver, ka mēs dzīvojam sarežğîtā, funkcionāli diferencētā sabiedrībā, un šī sarežğîtība kopš 18. gadsimta tikai pieaug. Sazarotāka un bezpersoniska ir kḷuvusi lēmumu pieņemšana, absolūta drošība nepastāv, un katrs lēmums potenciāli nes sev līdzi kādu riska iespēju.

N. Lūmans akcentē sociālo zinātṇu lomu riska problēmu risināšanā, viṇš norāda, ka riska novērtējums un gatavība uzņemties risku ir ne tikai psihologiiska, bet pirmām kārtām sociāla problēma. Sociālo zinātņu priekšplānā izvirzās jautājums: kas pieņem lēmumus, kas ir pats svarīgākais, nosakot to, vai risks būtu/nebūtu jāuzņemas u. tml. (Луман, 1994: 137).

Lūmans riska jēdzienu definē, diferencējot risku un bīstamību. Diferencēšana paredz, ka pastāv nenoteiktība vai nedrošība (Unsicherheit) attiecībā uz nākotnē iespējamo kaitējumu. Paveras divas iespējas. Viena iespējamo kaitējumu var uzskatīt par lēmuma sekām, t.i., to piedēvē lēmumam; tādā gadījumā runa ir par risku, precīzāk, par lēmuma risku. Otra iespēja kaitējuma iemesli var būt ārēji, proti, tie ir piederīgi apkārtējai pasaulei. Šāāā gadījumā runāts tiek par bīstamību (Луман, 1994: 150).

Sociologijai, uzskata Lūmans, ir jāizvirza jautājums par to, „kā sabiedrība skaidro un izlabo novirzi no normas, neveiksmi vai neparedzētu nejaušību [..]. Traucējuma skaidrojumu nevar uzticēt nejaušībai: nepieciešams parādīt, ka šim 
traucējumam ir sava kārtība, tā sakot, sekundārā normalitāte. Risks ir normālās formas pretējā puse, un, „vienīgi pievēršoties normālās formas pretējai pusei, mēs varam to identificēt kā formu" (Luhmann, 1993), proti, sabiedrības normālos procesus var izzināt, pētot to, kā sabiedrība cenšas apjēgt savas neveiksmes riska formā.

\subsubsection{Entonija Gidensa pieeja riska interpretācijā}

Britu sociologs Entonijs Gidenss (Anthony Giddens, dz. 1938), analizējot modernizācijas procesus un tās pāreju uz augstāko (refleksīvo) stadiju, pievērsās tiem sociuma struktūras elementiem, kuru transformācija rada riskus. Dzīvot „,vēlās modernitātes” (late modernity) laikmetā nozīmē dzīvot nejaušību un riska pasaulē. Riska jēdziens ien̦em centrālo vietu sabiedrībā, kura atvadās no pagātnes ar tradicionālajiem darbības veidiem un atveras neizpētītajai nākotnei (Giddens, 1991: 112). Šis apgalvojums vienlīdz attiecas uz risku gan institucionalizētā vidē, gan citās sfērās (Яницкий, 2001: 7).

Gidenss saista riska un riska sabiedrības izziņu ar refleksivitāti - vienu no centrālajiem savas teorijas jēdzieniem, ko viņš definē kā nepārtrauktu jaunu zināšanu uzṇemšanu, apguvi, kas kḷūst par sociālās organizācijas un pašidentitātes pamatu (Giddens, 1990).

Mūsdienu sabiedrība ir pakḷauta riskam, vēlamies mēs to vai ne; pat bezdarbība var izraisīt risku.-Analizējot riska ražošanas mehāniku, E. Gidenss uzsvēra, ka mūsdienu sabiedrību strukturē pārsvarā pašu cilvēku radītie riski. Šiem riskiem ir virkne atšķirīgu pazīmju. Pirmkārt, mūsdienu riski ir saistīti ar globalizāciju to „tāldarbības” ziṇā (kodolkarš). Otrkārt, risku globalizācija ir pieaugoša savstarpēji atkarīgo notikumu (piemēram, starptautiskās darba dalīšanas) skaita funkcija. Treškārt, mūsdienu pasaulē pastāv dažādas institucionalizētas risku vides, piemēram, investīciju tirgus - pasaule, no kuras 
stāvokḷa ir atkarīga miljoniem cilvēku labklājība. Risku ražošana ir dinamiska: informētība par risku ir risks, jo ,pārrāvumus” izziņas procesos vairs nevar - kā tas bija iepriekš - konvertēt reliğisko vai mağisko zināšanu „uzticamībā”. Ceturtkārt, mūsdienu sabiedrība ir pārsātināta ar zināšanām par riskiem, kas pati par sevi jau ir problēma. Piektkārt, Gidenss norādīja, ka būtiski pietrūkst ekspertu zināšanu kā risku eliminēšanas rīku sociālās sistēmās. Visbeidzot viņš ieviesa turpmākiem pārspriedumiem svarīgu mūsdienu sabiedrības riska vides jēdzienu, nošķirot trīs tā komponentus: (1) draudi un bīstamības, ko rada modernitātes refleksivitāte, (2) vardarbības pret cilvēku briesmas, kas izriet no karu industrializācijas, un (3) cilvēka eksistences bezmērķ̄īguma, bezjēdzīguma izjūtas izveidošanās draudi, ko rada cilvēka centieni samērot savu personisko eksistenci ar refleksīvo modernizāciju (Giddens, 1990:102-106, 124).

\subsubsection{Ulrihs Beks: riska koncepcijas skaidrojums}

Viena no plašākajām un konceptuāli pabeigtākajām riska sabiedrības koncepcijām pieder vācu sociologam Ulriham Bekam (Ulrich Beck, dz. 1944). U. Beks uzskata, ka risks nav ārkārtas gadījums, nav sabiedriskās dzīves „sekas” vai „blakusprodukts”. Sabiedrība pastāvīgi ražo riskus, turklāt šī ražošana notiek visās sabiedriskās dzīves jomās - ekonomiskajā, politiskajā, sociālajā. Riski ir neizbēgami lēmumu pieņemšanas produkti (Beck, 1992, 1994, 1995).

Risks, uzskata U. Beks, var tikt definēts kā sistemātiska sabiedrības mijiedarbība ar draudiem un briesmām, kuras inducē un ražo modernizācija (Beck, 1992b: 22). Risks ir mūsdienu jēdziens, kas sevī ietver kontroles jēdzienu un ņem vērā lēmumu pieņemšanu (Beck, 2002: 40). No brīža, kad sākās industrializācija, pastāvīgi ir sarukuši bada, epidēmiju vai dabas 
katastrofu draudi, bet ir parādījušies ,jauni riska veidi” (kodolieroči, ķ̄imiskā un biotehnologiskā rūpniecība utt.).

Riski - atšķirīibā no iepriekšējo laikmetu briesmām - ir sekas, kas saistītas ar modernizācijas draudošo spēku un tās radīto nedrošumu un bailēm (Beck, 1992b: 45). „Riska sabiedrība” faktiski ir jauna sabiedrības attīstības paradigma, kas saistīta ar to, ka industriālajā sabiedrībā valdošo „pozitīvo” sabiedriskās ražošanas log̣iku, t.i., bagātības uzkrāšanu un sadalīšanu, arvien vairāk pārklāj (izspiež) negatīvā ražošanas un risku izplatīšanās log̣ika.

U. Beks uzsver, ka riska sabiedrībā, ražojot labumus, tiek ražots arī sliktais - riski, kuriem ir pašiem sava loǵika un pie kuriem neesam pieraduši. Mūsdienu sabiedrības ideoloǵijas un politikas veidošanā l̦oti svarīga loma ir zinātnei, zināšanu ražošanai. Riska sabiedrības teorija postulē, ka, paplašinoties risku (īpaši megarisku) ražošanai, zinātnes loma sabiedrības dzīvē un politikā būtiski mainās. Lielāko daļu risku, kuri rodas zinātnes un tehnikas modernizācijas gaitā, turklāt visbīstamāko (radioaktīvā un ķ̄imiskā piesārņošana, nekontrolējamas gēnu inženierijas sekas), cilvēka maņu orgāni neuztver tieši. Šie riski pastāv vienīgi kā zināšanas par tiem. Speciālisti, kas atbild par jauno tehnologiiju un tehnisko sistēmu riska pakāpes noteikšanu, kā arī masu informācijas līdzekḷi, kas izplata par tiem zināšanas, „iegūst svarīgākās sociālās un politiskās pozīcijas" (Beck, 1992b: 23).

Vēl viena problēma ir tehnisko zinātņu un dabaszinātņu politiskā interpretācija. Š̄is zināšanas nevar tikt izmantotas tieši politiskajā procesā - ir nepieciešams to tulkojums politiskā dialoga un lēmumu valodā. Šo tulkošanu veic politiski angažēta zinātniskā sabiedrība, kura, „pārvēršas par faktoru, kas leǵitimē globālo rūpniecisko piesārņošanu, kā arī vispārēju augu valsts, dz̄ivnieku un cilvēku veselības sagraušanu un viņu bojāeju” (Beck, 1992b: 59). Veidojas ekspertu institūts, kas iegūst autonomu politisko nozīmi, jo tieši tas nosaka, kas un kādā mērā ir bīstams. Tieši eksperti nosaka sabiedrībai sociāli pieņemama riska pakāpi (Beck, 1995a: 15; Яницкий, 2001: 9). 
Svarīgas ir vēl citas riska sabiedrības teorijas nostādnes. Pirmkārt, ir jāpārskata sabiedrības pamata normatīvais modelis. Iepriekšējo laikmetu normatīvais ideāls bija vienlīdzība, riska sabiedrības normatīvais ideāls ir drošība. Sabiedrības sociālais projekts iegūst skaidri negatīvu un aizsardzības raksturu - nevis „labā” sasniegšana, kā tas bija iepriekš, bet gan „sliktākā” novēršana. Otrkārt, riska sabiedrībā veidojas jaunas sociālās kopības, kas nojauc vecās sociālās šḳērssienas. U. Beks uzskata, ka tās būs „risku upuru” kopienas, kuru solidaritāte uz satraukuma un baiḷu pamata var radīt varenus politiskos spēkus. Treškārt, riska sabiedrība ir politiski nestabila. Pastāvīgs spriegums un bailes no briesmām iešūpo politisko svārstu no vispārējas bīstamības un cinisma līdz neparedzamām politiskām darbībām, pieaug neuzticēšanās pastāvošajiem politiskajiem institūtiem un organizācijām (Beck, 1992b; Яницкий, 2001).

U. Beks nošķir trīs dažādas konflikta asis pasaules riska sabiedrībā: ekoloǵiskie konflikti, kas savā būtībā ir globāli; globālās finanšu krīzes, kuras sākotnēji var ,individualizēt un nacionalizēt”; globālie terorisma draudi, kas strauji aktualizējās pēc 2001. gada 11. septembra notikumiem ASV. Tas, ka šie riski ir globāli, nenozīmē, ka pasaule kḷūst vienveidīga vai ka visi reǵioni un kultūras tagad ir vienādi pakḷautas vienotam nekontrolējamu risku kopumam ekoloǵijas, ekonomikas un varas jomā. Nē, globālie riski ir sadalīti nevienmērīgi, tie atklājas dažādos veidos, atšķirīgi dažāaos vēsturiskos kontekstos, kā arī kultūras un politiskos modelıos (Beck, 2002: 41-42).

U. Beka izstrādātā „riska sabiedrības” pieeja izskaidro, kā mūsdienu sabiedrība risina dažādos riskus, kurus tā pati saražo un kuri ievērojami atškiras no tiem riskiem, ar kuriem pasaule saskārās pirms gadsimta. U. Beka darbi ir izpelnījušies plašu zinātnisku interesi un starptautisku atzinību, taču vienlaikus tie saņēmuši arī samērā izvērstu kritiku vienā vai otrā aspektā. Līdzīgi kā E. Gidenss tiek kritizēts par uzticēšanos ekspertu zināšanām, U. Beks tiek kritizēts par zinātnes lomas pārvērtēšanu sabiedrības riska apziņas radīšanā. 


\subsection{Riska uztveres pieejas}

Tiklīdz pētnieks izvirza mērķi noteikt risku indivīdam vai grupai (it īpaši - sociāli pieņemamu risku visai sabiedrībai), atklājas šā uzdevuma sarežğîtība, jo jebkura riska aprēķināšanas sistēma ir saistîta ar personiskām preferencēm, kultūru un politisko kontekstu. Šīs problemātikas analīzes klasisks paraugs ir Mērijas Duglasas un Ārona Vildavska darbs „Risks un kultūra” (Douglas \& Wildavsky, 1982, Яницкий, 2001).

M. Duglasa un $\bar{A}$. Vildavskis secina, ka draudiem ir jānosaka zināma prioritāšu skala, nevis jāveic vienkārša riskus izraisošo objektu uzskaite. Jāveic risku ranžēšana un novērtēšana, lai zinātu, ar kādiem riskiem jātiek galā un kādā secībā. Tas prasa iepriekšēju vienošanos par šādas vērtěšanas kritērijiem (Douglas \& Wildavsky, 1982: 3). Tā kā nav (un nevar būt) vienas vienīgas pareizās riska koncepcijas, tad nepastāv arī veids, kādā varētu likt visiem to pieņemt. No šejienes izriet Duglasas un Vildavska pētījuma galvenais teorētiskais secinājuma: „Risks ir uzskatāms par zināšanu par nākotni un vēlamāko perspektīvu saskaņotības kopproduktu.” „Kad zināšanas ir noteiktas, bet saskaņa pilnīga,” turpina autori, „kad pastāv vienošanās par mērķiem un visas alternatīvas (kopā ar to realizācijas varbūtībām) ir zināmas, iespējams izveidot labākā risinājuma realizācijas programmu. Šādā gadījumā problēmai ir tehnisks raksturs, un risinājums ir saistīts ar aprēķinu.. Tas nozīmēe, ka risinājums ir rodams pētǐšanā [..]" (Douglas \& Wildavsky, 1982: 4; sk. arī Яницкий, 2003: 12).

Duglasai un Vildavskim riska uztvere ir sociāls process, un jautājumi par riska pieņemamību jāizskata, ņemot vērā sociālos aspektus. To risku, par kuriem satraucas cilvēki, izvēle ir atkarīga no tām sociālajām dzìves formām, kurām tiek dota priekšroka. 
Riska uztveres teorijās visplašāk izplatîtā ir zināšanu teorija: tās pamatā ir priekšstats, ka cilvēki uztver tehnoloǵijas utt. kā bīstamas tādēḷ, ka viņi zina par to bīstamību. Cits vispārpieņemts nosacījums riska uztverē tiek atvasināts no personības teorijas. Indivīdi atbilstoši savai ievirzei pietiekami noturīgā veidā vai nu uzņemās risku, vai cenšas no tā izvairīties, kad vien tas ir iespējams (Wildavsky \& Dake, 1990: 167; MacCrimmon \& Wehrung, 1988; Mitchell, 1983). Kā norāda Ā. Vildavskis, trešais sabiedrības briesmu uztveres skaidrojumu kopums interpretējams ar divām ekonomikas teorijas versijām. Pirmā - bagātie labprātāk uzņemās risku, kas saistīts ar tehniku, jo gūst lielāku labumu no tā un ir kaut kādā veidā aizsargāti no nevēlamajām sekām. Savukārt mazāk turīgie, domājams, jūtas pavisam pretēji (Wildavsky \& Dake, 1990: 167). Otrā - „postmateriālistiskajā” versijā - pamatojums ir izvērsts tieši pretēji: tādēḷ, ka paaugstinājušies dzīves standarti, bagātie ir mazāk ieinteresēti tajā, kas viņiem pieder (pārpilnība) un kas viņiem to nodrošinājis (kapitālisms), bet vairāk tajā, ko viṇi gribētu saglabāt un iegūt (tuvība sociālajās attiecībās, labāka veselība) (Inglehart, 1977). Citi skaidrojumi par sabiedrības reakciju uz potenciālajām briesmām sakṇojas politikas teorijās, kuras strīdus par risku aplūko kā interešu cīṇu par stratēgisku amatu vai partijas priekšrocību u.tml. Interešu sadursmes politiskais modelis saista konfliktus ar cilvēku dažādo sociālo statusu sabiedrībā (Wildavsky \& Dake, 1990: 167). Šādā pieejā riska uztverei cerības uz izskaidrojumu tiek pārceltas uz sociāliem un demogrāfiskiem raksturlielumiem: dzimumu, vecumu, piederību noteiktai sociālai šķirai, liberāliem vai konservatīviem uzskatiem un/vai piederību politiskām partijām (Cotgrove, 1982; Nelkin \& Pollack, 1982; Wildavsky \& Dake, 1990: 167). Savukārt riska uztveres kultūras teorijā sociālās attiecības tiek attēlotas kā atšķirīgi cilvēku savstarpējo attiecību modeḷi - hierarhiskais, egalitārais un individuālais modelis (Вилдавски \& Дейк, 1994: 270).

Latvija nav izolēta sala, un arī mūs var skart kā vietējās sabiedrības, tā globālo procesu rezultātā radušies apdraudējumi. Tādēl ir svarīgi noskaidrot, 
cik lielā mērā Latvijas iedzīvotāji apzinās savu vietu globālā risku sabiedrībā, cik lielā mērā apzinās ekologískos riskus, kā arī to, kādas stratēgijas būtu mērḳtiecīgāk izvirzìt šo risku mazināšanā.

\section{EKOLOĢISKO RISKU KONCEPCIJA UN IZPĒTE}

\subsection{Ekoloǵiskie riski riska sabiedrības teorētiskajā koncepcijāā \\ 2.1.1. Dabas socializācija: ekoloǵisko risku aizsākums}

Sabiedrības attīstības gaitā notiek aizvien plašāka un dziḷāka „dabas socializācija" ${ }^{3}$ - dabas, proti, dabas sistēmu iesaistīšana sabiedrības un cilvēka dz̄ivēe (taču bieži vien tas notiek, vadoties nevis pēc dabas iespējām, bet cilvēka vajadzībām); dabas pārveide atbilstoši cilvēka vajadzībām (bieži vien nerēķinoties ar dabas spēju šo socializāciju ,izturēt”); proporciju izjaukšana dabā, vieglprātīgi izturoties pret pašas dabas noteiktām proporcijām (piemēram, ūdeņu dabisko spēju attīrīties u.tml.). Jāatzīmē dabas socializācijas divatnīgais raksturs. Dabas socializācija daudzus sociālās attīstības procesus ir padarījusi vienkāršākus, bet vienlaikus ir atklājusies šā procesa otra šķautne - dažādi ekoloǵiskie riski. Taču, kā uzsver U. Beks, sabiedrība ar ekspertu starpniecību saņem riska, t.sk. ekologiiskā riska, novērtējumu jeb sociāli pieņemamo līmeni (Beck, 1995b), un zinātniskajai sabiedrībai ir jānodrošina tā saucamā riska līmeņa iztulkošana plašākai sabiedrībai.

${ }^{3}$ Dabas socializāciju definē kā dabas universālas izmantošanas pastiprināšanos un cilvēku vispārējas atbildības pieaugumu par tās saglabāšanu (Яценко, 1999). 


\subsubsection{Ekoloğisko risku aktualizēšana: „Jaunā ekoloğiskāa paradigma"}

Vieni no pirmajiem, kas 20. gs. 70. gadu nogalē ieinteresējās par vides jeb invaironmentālo sociologiju, bija amerikāņi Viljams Katons (William Catton) un Railijs Danleps (Riley Dunlap) (Catton \& Dunlap, 1979). 20. gadsimta pēdējās desmitgadēs socioloǵija ir pievērsusies ar̄̄ vides apziņai. Antropocentriskajāa, sociocentriskajā un „optimistiskajā”, pieejā sabiedrisko parādību izpētei radās plaisas, kuras aizpildīja sintētiskā pieeja.

Pagājušā gadsimta beigās sociologijā tika formulēti vairāki svarīgi principi. Viens no tiem: sociālo rada ne tikai sociālie, bet arī dabas/vides faktori. Tāpēc daba un sabiedrība vairs netiek šķirtas, pastāv to simbioze, socializētā daba. Šo principu mūsdienu sociologijiā pārstāv ,jaunā ekologiskāā paradigma” (JEP; New Environmental Paradigm), kurā ,ārējie” ekoloǵiskie (vides) ierobežojumi, kas uzlikti cilvēku darbībai, tagad tiek interpretēti kā sociālie faktori, t.i., kā iekšējie sociālie sabiedriskās dzīves regulatori (Dunlap \& Van Liere, 1978: 10). Katons un Danleps formulēja arī četras JEP pamatnostādnes (Catton \& Dunlap, 1980: 34).

Promocijas darba 2.1. tabulā detalizēti izvērtētā (1) JEP ar vides reālisma ideju atspoguḷojumu pētījumos, kas veikti 20. gs. 70. gados un publicēti šīs desmitgades beigās, kā arī (2) vides konstruktīvisms, kas attīstījās kopš 90 . gadiem, līdz ar U. Beka, E. Gidensa, N. Lūmana u.c. atzin̄ām par riska sabiedrību, tiek uzskatīti par būtiskākajiem sociolog̣ijas virzieniem, kas pievērsušies vides problēmu izpētei. R. Lidskogs ir sniedzis abu virzienu konspektīvu salīdzinājumu (sk. promocijas darba 2.2. tabulu). 


\subsubsection{Ekoloğisko risku uztveres un izvērtēšanas modelis}

Riska sabiedrībā ir akūti nepieciešams zināt, kā cilvēki uztver un izvērtē riskus, tostarp arī ekoloǵiskos riskus. Literatūrā tiek uzmanība pievērsta diviem virzieniem riska izpētē un uztverē: (1) atšķirīibu izpēte riskogēnās darbībās un (2) individuālās riska uztveres izpēte. Pirmā virziena pārstāvji uzskata, ka termins riska uztvere nav īsti precīzs - būtībā risks nav uztverams, uztverami ir tikai lēmumu rezultāti. Tāpēc faktiski nav termina objektīvais risks (Singleton \& Hovden, 1987: 26, nо Гришаев, 2002: 26).

Otra virziena piekritēji piedāvā šādu riska definīciju: „Risks - tā ir nenoteikta situācija, kurā viens vai vairāki iznākumi (outcomes) nav vēlami” (Merkhofer, 1987: 2). Sekas var parādīties dažādos sociālās sistēmas līmeṇos kā cilvēka veselības pasliktināšanās, apkārtējās vides stāvokḷa parametros vai pašas sistēmas attīstībā. Lai precīzāk formulētu riska jēedzienu, tiek skaidrots riska ǵenerācijas process, kurā dominē trīs komponenti: (1) riska avots, proti, briesmas/draudi (hazard), (2) draudu izpausme un (3) draudu izpausmes efekts jeb rezultāts (Schaefer, 1978; Гришаев, 2002: 30).

Draudi, to izpausme un rezultāti jeb efekti nosaka riska apjomu ar briesmu seku iespējamību un līmeņa novērtēšanu. Riska uztveršana „pievieno” papildu komponentu - indivīdu vai visas sabiedrības sniegto iespējamo seku nozīmes novērtējumu. Visi komponenti kopā veido tā saucamo „riska ķēdi” (risk chain) jeb riska ǵenerēšanas procesu.

Apkopojot aplūkotās teorētiskās nostādnes, var secināt: jebkuriem draudiem ir noteikta efektu kopa, kas noteiktos apstākḷlos izpaužas; jebkura sabiedrības dzīvības procesa norise, kas notiek, patērējot dabas resursus, rada risku, kas savukārt maina pastāvošās sabiedrības pamatnostādnes un rada problēmas turpmākai veiksmīgai dzīvības procesu norisei; dabas socializācija atvieglo sabiedrības eksistenci, tomēr cilvēku iejaukšanās dabas pasaulē 
provocē ekologiisko risku rašanos; JEP rašanās aktualizēja ekologisko problēmu nozīmi, popularizēja uzskatu, ka dabas aizsardzībai ir jākḷūst prioritārai salīdzinājumā ar ekonomisko izaugsmi; sociologijāa riska analīzei ir raksturīgs risku apraksts, kā arī to iedabas un attīstības skaidrojums; galvenās riska analīzes sfēras ir ekologiskie riski un sociālo procesu radītie riski, orientējoties uz sabiedriskās domas aktivizēšanu jautājumos par analizējamajiem riskiem un „veselīgu alarmismu”.

\subsubsection{Ekoloǵiskā apziṇa un ekoloğiskā uzvedība: uzskati un rīcība}

Lai raksturotu cilvēka attieksmi pret vidi, teorētiskajā literatūrā lieto jēdzienu ekologiskā apziņa / vides apziņa. Abu jēdzienu nozīmes ir visai tuvas, taču nav identiskas. Sadą̧ā aplūkoti un salīdzināti vairāku pētnieku priekšstati par to, kas ir ekologiiskā apziņa, sniegts izvērsts tās raksturojums (M. Kristofers (Michael Christopher) no Havaju Universitātes Hilo, kanādiešu zinātnieki E. O'Sallivans un M. M. Teilore (Edmund O'Sullivan, Marilyn M. Taylor), Pensilvānijas Universitātes biologijas profesors K. Ūls (Christoph Uhl) u.c.)

Šaurākā nozīmē ekologiskā apziṇa attiecas uz specifiskiem psihologiskiem faktoriem, kas saistīti ar indivīda tieksmi iesaistīties uz vidi orientētās (proinvaironmentālās) darbībās, savukārt plašākā nozīmē tā iekḷauj psihologiskus, vērtību un uzvedības faktorus - uzskatus, attieksmes, zināšanas, zināšanu un vērtību determinētu rīcību u.c. Analītiskā skatījumā ekoloǵiski apzin̄̄gs (uz vidi orientēts) indivīds ir tāds, kam raksturīga plaša spektra uz vidi orientēta darbība un kurš reprezentē noteiktas vērtības un uzskatus (Sanchez \& Lafuente, 2010: 732).

Ekologiskā/vides apziņa var tikt konceptualizēta četrās dimensijās: emocionālā, dispozicionālā, kognitīvā un aktīvā. 
Latvijas sociologi V. Meņšikovs un A. Kalniņa, raksturojot Latvijas iedzīvotāju ekoloǵisko apzinīgumu jeb ekoloǵisko apziņu, nošķir tajā trīs komponentus: 1) norūpētība par vides degradāciju; 2) gatavība ieguldīt laiku un līdzekḷus vides uzturēšanā; 3) zināšanas par vidi degradējošiem faktoriem (Kalniņa \& Menšsikovs, 2004: 49). Promocijas darba autore, veidojot zinātniskā darba koncepciju, lieto savu Latvijas kolēǵu piedāvāto ekologiskās apziņas trīskomponentu definējumu, kā arī ar ekologisko apziņu saprot holistisku pieeju realitātei, apzināšanos, ka faktiski ikviens cilvēku dzīves aspekts ietekmē vidi (sk. arī Christopher, 1999; Leff, 1978; Sanchez \& Lafuente, 2010; O`Sullivan \& Taylor, 2004; Uhl, 2003).

Vides aizsardzības un ekoloǵisko jautājumu izpētē iezīmējas specifiskas tēmas (tostarp ekologiskie riski), kuru padziļināta izziņa dod iespēju izprast esošās tendences un formulēt iespējamās sekas. Lai vērtētu ekoloǵisko risku ietekmi, svarīgi iegūt ne tikai iedzīvotāju subjektīvo vērtējumu, bet jāaplūko arī objektīvie rādītāji, kas to raksturo. Šajā kontekstā promocijas darba autore padziļināti pievērsusies Marka Hadlera (Marcus Hadler) un Maksa Hallera (Max Haller) (Hadler \& Haller, 2011) atzin̄ām par indivīda uzvedības veidiem (publiskā un privātā) vides aizsardzībā. Uzmanības lokā ir arī individuālā līmeņa sociodemogrāfiski indikatori, kas ietekmē iedzīvotāju vides uzvedības paradumus.

Šajā sadaḷā aplūkoti arī jautājumi, kas saistās ar ekoloǵiski atbildīgu uzvedību patēriņa jomā, analizēti pētîjumi par cilvēku reālo rīcību vides aizsardzībā un rīcība salīdzināta ar viṇu paustajiem videi draudzīgajiem uzskatiem, jo cilvēku teiktais ne vienmēr saskan ar viṇu darbību (Schlossberg, 1990; Roberts \&, Bacon, 1997: 89; Ajzen, 1989; Dalton, 1994; Gillham, 2008). 


\subsection{Pêtījumi par ekolog̣ijas problemātiku Latvijā}

Vides problēmu pētniecība kopējā Latvijas pētījumu kontekstā. 20. gs. otrajā pusē, vides problēmām iegūstot arvien svarīgāku vietu sabiedrības dzīvēe, sabiedriskās domas pētnieki un sociologi uzsāka pētījumus, lai noskaidrotu sabiedrības informētības līmeni ekolog̣isko risku un vides aizsardzības jomā. Sākotnēji pētījumi dokumentēja sabiedrības informētības līmeni, kā arī izvērtēja dabas aizsardzības interešu pārmaiņas dažādās (atšķirīga izglītība, vecums, dzīvesvieta) iedzīvotāju kategorijās (Albrecht, 1975: 560). Tālākie pētījumi l̦āvuši analizēt arī iedzīvotāju uzmanīgāku attieksmi pret vides aizsardzību, viṇu ekolog̣iskās apziņas līmeni un tā saistību ar ikdienas paradumiem vides aizsardzībā.

Lai vērtētu līdzšinējos pētījumus par Latvijas iedzīvotāju viedokḷiem saistībā ar vides aizsardzības problēmām kā iespējamu risku, tika atlasīi 12 pētījumi, kuri vai nu pilnībā ir veltīti vides aizsardzības jautājumiem vai skar atsevišķus tās aspektus (pētījumu sarakstu sk. promocijas darba 2.3. tabulā).

Veicot minēto pētījumu datu viendimensionālo analīzi, tika noskaidrota Latvijas respondentu attieksme pret ekologisko problemātiku ilgtermiņā. Datu analīze strukturēta sešās apakštēmās, kuras iztirzātas nākamajās sadạ̧ās. Saturiski tajās apkopoti un analizēti lielākoties tie jautājumi, kas ietverti promocijas darba trešās nodą̧as pētāmajos jautājumu moduḷos.

Atsevišķu jautājumu dziḷākai izpratnei veikts salīdzinājums ar citām pasaules valstīm.

Vides jautājumu aktualitāte iedz̄votāju vērtējumā kā viens no ekoloğiskās apziṇas pamatrādītājiem. Pētījumos ir vākta informācija par vides jautājumu aktualitāti iedzīvotāju vērtējumā. Pieaugot apziņai par visas pasaules un katras atsevišķas valsts un indivīda atbildību par vides aizsardzību, iedzīvotāji vides aizsardzības jautājumus ierindo to būtisko jautājumu lokā, kuriem piešķirama īpaša nozīme. Šì izpratne par apkārtējo vidi kā nozīmīgu 
faktoru ir arī viens no iedzīvotāju ekoloǵiskās apziņas rādītājiem (Dunlap \& Van Liere, 2000; Capra, 2003; O`Sullivan \& Taylor, 2004; Kalniņa \& Meņšikovs, 2003). Dati liecina, ka Latvijas iedzīvotāju viedoklis būtiski neatšķiras no lielas daļas Eiropas valstu iedzīvotāju viedokl̦a

Kopumā var secināt, ka Latvijas iedzīvotājiem rūp vides aizsardzības jautājumi un viņus uztrauc iespējamās sekas, ko var izraisīt cilvēka iejaukšanās dabā. Cilvēki pauž viedokli, ka apkārtējās vides aizsardzībai ir svarīga loma viņu dzīvē un valsts dzīvē kopumā, tomēr, saistot atbalstu vides aizsardzībai ar iespējamu ekonomiskās attīstības palēnināšanos, atbalsts vides aizsardzībai kḷūst mazāks.

Vides aizsardzības jautājumu identificēšana: bažas par ekoloğiskajiem riskiem. Analizējot pētījumu datus, tika vērtēts, vai un cik lielā mērā iedzīvotāji ekolog̣isko situāciju raksturo kā riskantu un apdraudošu, jo viens no ekoloǵiskās apziņas indikatoriem ir iedzīvotāju bažas par vides situāciju (Dunlap \& Van Liere, 1978). Pētîjumu dati liecina, ka Latvijas iedzīvotāji ir nobažījušies par vides situāciju. Iedzīvotāji apzinās ekoloǵisko situāciju kā potenciāli draudošu, un viņi pauž bažas par planētas nākotni tieši saistībā ar ekologisko situāciju un cilvēka radītiem apdraudējumiem dabai.

Pētījumā „Cilvēkdrošība Latvijā” respondentiem tika lūgts izteikties par 32 iespējamiem apdraudējumu iemesliem. Apkopojot respondentu atbildes, var secināt, ka četri no desmit iemesliem, kas lika cilvēkiem baidīties visvairāk, ir saistīti ar vidi (sk. Latvija. Pārskats par tautas attīstību 2002/2003).

Iedzīvotāju gatavība iespējamās ekolog̣iskās krīzes risināšanai: sabiedrības vērtējums. Šajā sadaḷā analizēts viens no pirmajiem plašākajiem pētījumiem ekoloǵisko risku jomā Latvijā - 1999. gadā Daugavpils Pedagoǵiskās universitātes zinātnieku veiktais pētījums „Atomenerḡêtika un cilvēka dzīves apstākḷi”, kas bija saistīts ar Ignalinas AES (Lietuva) radīto ekoloǵisko risku izvērtēšanu un ietekmi uz apkārtējo teritoriju iedzīvotāju dzīves kvalitāti. Tika noskaidrots, ka lielākā daļa iedzīvotāju un ekspertu 
Latvijā atzīst AES bīstamo ietekmi uz apkārtējo vidi: 89\% Daugavpils rajonā aptaujāto iedzīvotāju uzskatīja, ka AES rada apdraudējumu dabai, 88\% norādīja, ka AES apdraud arī cilvēku veselību. Vislielākās briesmas dabai, pēc respondentu domām, rada gaisa piesārņošana (šo atbildi minēja 71\% iedzīvotāju), otrajā vietā - radioaktīvais starojums (64\%) (Meņšikovs \& Peipiņa, 1999: 5).

Pētījums uzrādīja nepieciešamību attīstìt ekologisko apziņu, kas kopumā nozīmē ne tikai bažas par apkārtējās vides stāvokli, bet arī pietiekamu informētības līmeni par konkrēto risku, lai varētu izstrādāt atbilstošus rīcības modeḷus. Var secināt, ka iedzīvotāju lielākā daḷa savu sabiedrisko uzvedību nevar noteikt un konkretizēt adekvāti reālajai ekolog̣iskajai situācijai reǵionā.

Iedzīvotāju informētība par vides aizsardzības jautājumiem. Ekoloǵisko apziṇu raksturojošs elements ir iedzīvotāju informētība par vidi degradējošiem faktoriem, un tas paredz zināšanas par vides aizsardzības jautājumiem kopumā. Pētījumos respondenti norāda, ka vides jautājumi tiem ir svarīgi, tomēr viṇi atzīst, ka par vides problēmām un vides aizsardzības jautājumiem kopumā ir informēti ne pāāāk labi, nav arī precīzas informācijas par iespējamo apdraudējuma apjomu un rīcību iespējamo kaitīgo seku iestāšanās gadījumā. Pieaugot iedzīvotāju informētības līmenim par vides riskiem un iespējām tos novērst vai ar tiem sadzīvot, pieaugs arī iespēja panākt viņu aktīvu un apzinātu līdzdalību šo risku vadīšanā un novēršanā.

Sabiedrības ieguldījums vides aizsardzības pasākumos: iedzīvotāju vērtējums. Izvaicāti par aktīvām darbībām vides aizsardzības labā, liela dạ̦a Latvijas iedzīvotāju galveno atbildību par vides piesārņošanu vēlas delegét lielajiem uzņēmumiem un valstīm (starptautiskām organizācijām). Iedzīvotāji ir gatavi uzņemties atbildību tādos vides aizsardzības pasākumos, kas neprasa jūtamus finansiālus ieguldījumus vai aktīvu darbošanos.

Iedzīvotāju aktivitāte vides aizsardzībā: ikdienas paradumi un publiskās aktivitātes. Vērtējot datus, jāṇem vērā ne tikai iedzìvotāju 
deklaratīvi paustais viedoklis par vides jautājumu aktualitāti, bet arī viṇu ikdienas paradumi un gatavība tos mainīt apkārtējās vides kvalitātes uzlabošanas vārdā.

Dati liecina, ka aizvien prāvāka Latvijas iedzīvotāju daḷa uzskata, ka vinuu loma vides aizsardzības pasākumu uzlabošanā var būt nozīmīga. Iedzīvotāji arī apliecina gatavību veikt ikdienas paradumu korekciju par labu videi, ja tas neprasīs papildu ieguldījumus vai prasīs salīdzinoši nelielus finansiālus vai personiskās līdzdarbības ieguldījumus: piemēram, atkritumu šķirošana, videi draudzīgu preču izvēle, atbalsts vietējo ražotāju izstrādājumiem.

Analizētie pētījumi sniedz labu ieskatu Latvijas iedzīvotāju viedoklī par vides problēmām, iedzīvotāju norūpētību un zināšanām par šiem jautājumiem kopumā no viendimensionālās analīzes skatupunkta. Autore, analizējot pētījumus, kuros raksturoti apkārtējās vides jautājumi, ir identificējusi un apkopojusi datus, kas veido priekšstatu par ekoloǵisko problemātiku Latvijā un tās uztveri. Tomēr, lai varētu analizēt pilnvērtīgi Latvijas iedzīvotāju ekoloǵisko apziņu, ir nepieciešams (balstoties uz ārzemju un Latvijas pētniecības tradīcijām šajā jomā) izveidot indikatoru sistēmu, kas ļautu mērīt un raksturot tieši Latvijas iedzīvotājiem raksturīgo ekoloǵisko apziņu un uzvedību, kā arī pētīt ekoloǵiskās apziņas un uzvedības mijiedarbību. Šo datu savstarpējās saistības būtu pārbaudāmas ar daudzdimensionālās analīzes palīdzību, bet iegūtie rezultāti l̦autu izstrādāt atbilstošus instrumentus valsts politikas realizēšanā, kas savukārt palīdzētu paaugstināt iedzīvotāju ekolog̣isko apziṇu, tādējādi sistematizējot un nostiprinot iedz̄ivotāju ekoloǵiski atbildīgas uzvedības tradīcijas. 


\section{IEDZĪVOTĀJU VĒRTĒJUMS PAR RISKA SABIEDRĪBU UN EKOLOG̣ISKAJIEM RISKIEM LATVIJĀ}

3.1. Aptaujas metodoloğija

Promocijas darba (turpmāk - PD) 2. nodaļā tika analizēti vairāki pētījumi un interpretēti dati atbilstoši Ievadā definētajiem moduļiem. Lai izpētîtu Latvijas iedzīvotāju ekologiskās apziṇas komponentus, to savstarpējās saistības un noskaidrotu viņu subjektīvo vērtējumu par riska sabiedrību un ekoloǵisko risku, kā arī apzinātu galvenos faktorus, kas veido Latvijas iedzīvotāju priekšstatus par riska sabiedrību (norūpētību par vides degradāciju), noskaidrotu un novērtētu iedzīvotāju informētības līmeni jeb zināšanas un analizētu iedzīvotāju informētības līmeņa lomu ekologiisko risku apzināšanās procesā un analizētu Latvijas iedzīvotāju gatavību darbībām, lai mazinātu jaunu ekoloǵisko risku rašanos un esošo pastiprināšanos, ir svarīgi noskaidrot vispārējo attieksmi pret vides aizsardzību, analizēt ekologisko risku satura vērtējumu un informētību par ekologiskajiem riskiem, novērtēt aktivitātes riska mazināšanai. Šim nolūkam PD trešajā nodaḷā kā informācijas ieguves veids tika izmantota kvantitatīva informācijas ieguves metode. Ar tās palīdzību tika iegūti primārie kvantitatīvie dati par visiem pētnieciskajiem jautājumiem, kas izvirzīti ievadā formulētajos pētījuma uzdevumos. Tika izstrādāts pētījuma instruments - speciāla, dal̦eji standartizēta anketa (sk. PD) 1. pielikumu). Balstoties uz PD 2.2. sadaļāa analizētajiem pētījumiem par dažādiem ekoloǵiskiem jautājumiem un teorētiskajā dą̧ā iegūtiem secinājumiem, anketa tika papildināta ar specifiskiem jautājumiem par ekoloǵiskajiem riskiem un riska sabiedrību, un tas sekmēja promocijas darba izvēlētās tēmas analīzi. Lai gan anketā salīdzinājumam ir iekḷauti jautājumi no dažādiem citiem pētījumiem, šāds anketas saturs par ekolog̣isko tematiku ir oriǵināls un aprobēts promocijas darba aptaujā pirmo reizi. 
PD autores personiskais ieguldījums PD kvantitatīvā pētījuma tapšanā ir aptaujas anketas izstrāde, atbilstošās metodes izvēle, speciāli apmācītu intervētaju izvēle, kvalitātes kontroles (10\% apjoma) veikšana. Uzsākot kvantitatīvo pētījumu, autore sagatavoja analīzes modeli (2. att.), nosakot pētāmo jautājumu tematiskos moduḷus un galvenos jautājumus katrā no tiem, kā arī pētāmo jautājumu moduḷu sagaidāmo savstarpējo saistību. Autore aptaujā koncentrējas uz pieciem pētāmo jautājumu tematiskajiem moduḷiem.

1) Attieksme (aktuālo problēmu novērtējums, vides aizsardzība, vides un ekonomisko jautājumu mijiedarbība, atbildība par rūpēm vides aizsardzības jomā, vides problēmu aktualitāte).

2) Ekoloğisko risku satura vērtējums (pakḷautība ekoloǵiskajiem riskiem, riskus izraisošo tautsaimniecības procesu novērtējums, ekoloǵisko risku izraisītā kaitējuma novērtējums, ekoloǵisko risku satura identificēšana).

3) Priekšstati par riska sabiedrību (riska sabiedrības pazīmju vērtējums).

4) Informētība par ekologiskajiem riskiem un mediji (informētība par riskus izraisošajiem tautsaimniecības procesiem, informētība par ekoloǵisko risku izraisītajiem kaitējumiem, informācijas avoti par ekolog̣iskajiem riskiem, informētība par rīcību dažādu ekologisisko avāriju gadījumos).

5) Aktivitātes riska mazināšanā (gatavība iesaistīties vides uzlabošanas aktivitātēs, dalība vides aizsardzības pasākumos).

Papildus tika aplūkots sociāldemogrāfisko faktoru bloks un tā saistība ar visiem iepriekšminētajiem jautājumu blokiem, pieņemot, ka šiem faktoriem ir lielāka/mazāka ietekme uz visiem pētāmo jautājumu tematiskajiem moduḷiem. 


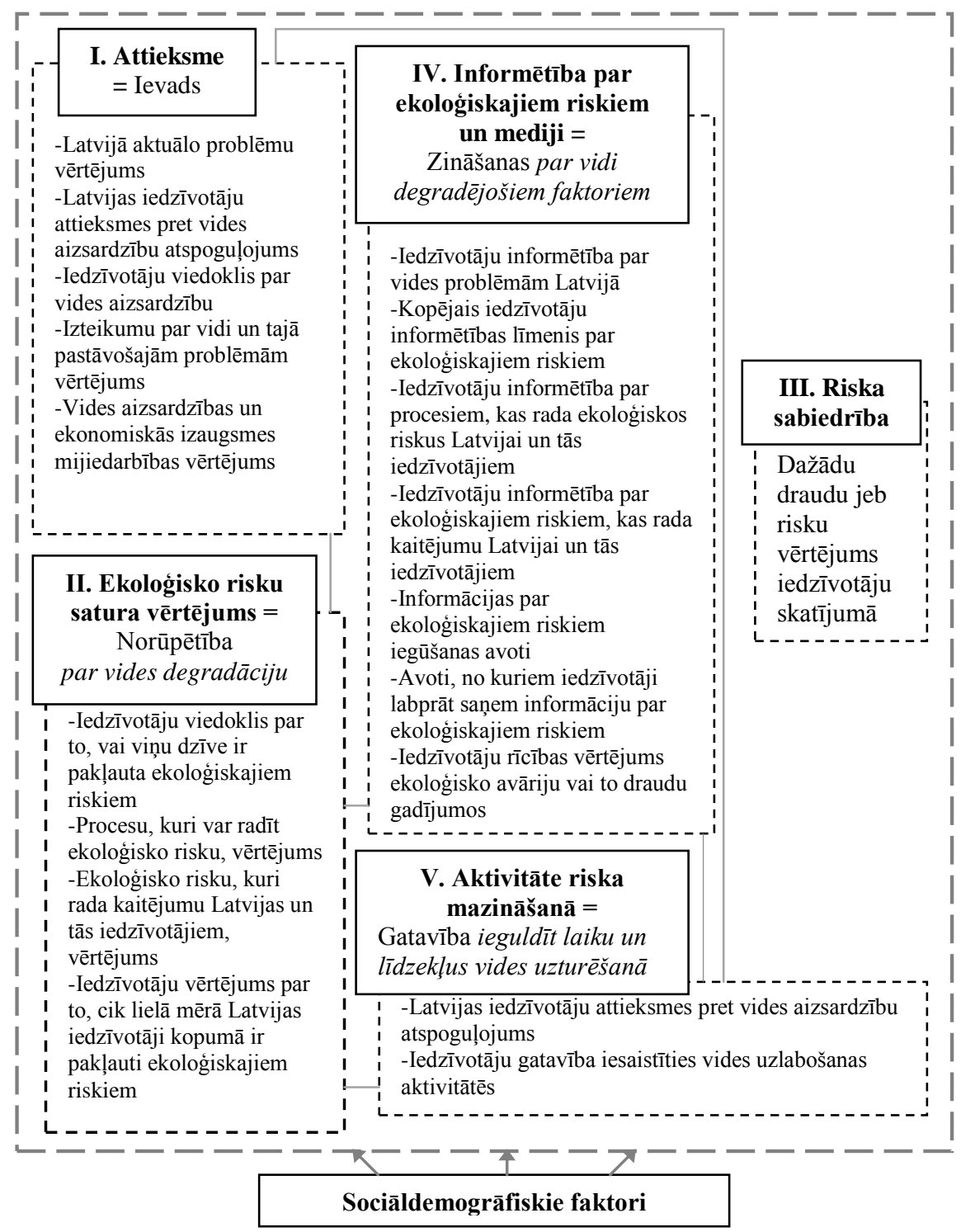

2. attēls. Pētījuma modelis ${ }^{4}$

4 Aptaujas shematiskais modelis veidots, balstoties uz Eiropas Sociālo pētījumu programmas labklājīibas pētījumu model̦a paraugu (Welfare attitudes in a changing Europe: module template with background information, survey questions to be used in ESS Round 4, European Social Survey). 
Veidojot aptaujas anketu, autore izmantoja iepriekšējos gados veiktos pētījumos (EVS, WVS, ISSP, EB, Cilvēkdrošība Latvijā un Atomenrgètika un cilvēka dzīves apstākļi) lietotos indikatorus un mērījumu skalas, adaptējot un piemērojot tos promocijas darbā izvirzītā mērķa un uzdevumu realizācijai. Izlases veidošanai tika izmantota vairākpakāpju nejaušā izlase, ņemot vērā to, ka katram elementam no ǵenerālās kopas pastāv zināma varbūtība tikt iekḷautam izlasē. Tika zvanīts uz mobilo un fiksēto telefonu numuriem.

Lai nodrošinātu plānotās izlases apjomu $\mathrm{n}=800$, kopējais kontaktu mēginājumu skaits bija 8168. Aptaujas laukdarba kvalitātes kontroles un datu ievades kvalitātes pārbaudes gaitā par rezultātu analīzei nederīgām tika atzītas četras anketas. Pabeigto interviju skaits bija 817 , no kurām tālākai datu analīzei par derīgām tika atzītas 813 anketas. Nerespondences skaits sasniedza $n=7355$ (nerespondences uzskaiti sk. promocijas darba 2. pielikumā).

Datu ievade notika RM PLUS WARP-IT programmā. Atvērtie jeb teksta jautājumi anketās tika pierakstīti brīvā tekstā un pēc tam kodēti.

Datu validitātes un ievades kvalitāte tika kontrolēta un nodrošināta saskan̄ā ar starptautisko metodologiju (ESOMAR standartiem), pārbaudot 10\% no ievadītajām aptaujas anketām.

Pēc datu ievades apkopotais materiāiuls tika pārnests no RM PLUS WARP-IT DATA ENTRY programmas uz SPSS 19.0 Tālākā datu apstrāde tika veikta, izmantojot šo programmu

Dati tika pakḷauti svēršanas procedūrai, balstoties uz LR IeM PMLP Iedzīvotāju reǵistra sniegto jaunāko statistisko informāciju par Latvijas iedzīvotāju skaitu, dzimumu, vecumu un reǵionu sadalījumā.

\subsection{Iedzīvotāju attieksme pret vides aizsardzību}

\section{Latvijas problēmu kontekstā}

Saskaņā ar U. Beka pieeju risks var tikt definēts kā sistemātiska sabiedrības mijiedarbība ar draudiem, kas tiek inducēti un ražoti modernizācijas 
procesa gaitā. Industrializācija ir radījusi jaunus riska veidus, turklāt globalizācijas procesu rezultātā paplašinās arī risku potenciālo kaitīgo seku robežas (Beck, 1992, 2002). Viens no globālajiem riskiem ir ekologiskais risks, kam šajā pētījumā pievērsta centrālā uzmanība.

Šajā nodaļā aplūkoti jautājumi, kas raksturo iedzīvotāju vispārējo viedokli par problēmām Latvijā un vides aizsardzību kopumā. Tika izvirzītas hipotēzes un attiecīgi veikta analīze par iedzīvotāju norūpētību par vides degradāciju, t.i., problēmām un situāciju šajā jomā ne tikai viendimensionālās analīzes līmenī, bet arī matemātiski pārbaudīta šo moduḷu priekšstatu sistēmu - problēmu hierarhija (1), valsts - indivīds (2) un ekonomiskais ieguldījums (3) savstarpējā saistība. Pētījuma gaitā visas izvirzītās hipotēzes apstiprinājās.

3.4. tabula

\section{Hipotēžu pierādījumu kopsavilkums}

\begin{tabular}{|c|c|c|}
\hline 1. & $\begin{array}{l}\text { Latvijas iedzīvotāji vides problēmas sociālo problēmu } \\
\text { kontekstā ierindo pie aktuālajām problēmām }\end{array}$ & $\begin{array}{l}\text { Hipotēze } \\
\text { apstiprinās }\end{array}$ \\
\hline 2. & $\begin{array}{l}\text { Pastāv statistiski būtiska saistība starp viedokli ,,ūp/nerūp” } \\
\text { vides aizsardzība un viedokli par to, cik aktuālas ir vides } \\
\text { problēmas valstī }\end{array}$ & $\begin{array}{l}\text { Hipotēze } \\
\text { apstiprinās }\end{array}$ \\
\hline 3. & $\begin{array}{l}\text { Jautājumā par atbildības sadalījumu vides aizsardzībā - valsts } \\
\text { vai indivīds - Latvijas iedzīvotāji uzskata, ka atbild̄̄ba ir } \\
\text { jāuzņemas kā pašiem iedzīvotājiem, tā arī valstij }\end{array}$ & $\begin{array}{l}\text { Hipotēze } \\
\text { apstiprinās }\end{array}$ \\
\hline 4. & $\begin{array}{l}\text { Pastāv statistiski būtiska saistība starp iedzīvotāju viedokli, ka } \\
\text { valdībai jāsamazina apkārtējās vides piesārnotīiba, bet ne par } \\
\text { iedzīvotāju līdzekliem, un iedzīvotāju viedokli, ka } \\
\text { ekonomiskajai izaugsmei un jaunu darbavietu radīšanai ir jābūt } \\
\text { prioritātei, pat ja tādēl zināmā mērā cieš vide }\end{array}$ & $\begin{array}{l}\text { Hipotēze } \\
\text { apstiprinās }\end{array}$ \\
\hline 5. & $\begin{array}{l}\text { Pastāv statistiski būtiska saistība starp iedzīvotāju viedokli } \\
\text { piekrist nodokḷu paaugstināšanai, ja ir pāāliecība, ka šī nauda } \\
\text { tiks izmantota vides piesārṇotības mazināšanai, un viedokli, ka } \\
\text { vides aizsardz̄̄bai ir jābūt prioritātei, pat ja tas nozīmētu lēnāku } \\
\text { ekonomisko izaugsmi un zināma skaita darbavietu zaudēšanu }\end{array}$ & $\begin{array}{l}\text { Hipotēze } \\
\text { apstiprinās }\end{array}$ \\
\hline 6. & $\begin{array}{l}\text { Pastāv statistiski būtiska saistība starp viedokli ,,rūp/nerūp” } \\
\text { vides aizsardzība un viedokli, ka par vides aizsardzību } \\
\text { jārūpējas gan valdībai, gan iedzīvotājiem }\end{array}$ & $\begin{array}{l}\text { Hipotēze } \\
\text { apstiprinās }\end{array}$ \\
\hline
\end{tabular}


Pārbaudot, kā sociāldemogrāfiskie faktori ietekmē Latvijas iedzīvotāju sniegtās atbildes vispārējo problēmu vērtējumā (šo problēmu uzskaitījumā iekḷauti arī apkārtējās vides jautājumi), ar $\chi^{2}$ testa palīdzību tika konstatēts, ka ne visi sociāldemogrāfiskie faktori ietekmē viedokli par apkārtējās vides problēmām. Latvijas iedzīvotāju izteikto vides problēmu aktualitātes vērtējumu ietekmē iedzīvotāju izglītības līmenis un dzīvesvietas tips - lauki, pilsēta vai Rīga. Tas nozīmē, ka, analizējot un interpretējot šo jautājumu, jāpievērš uzmanība tam, ka vides problēmas kā aktuālas lielākoties uztver respondenti ar vidējo un augstāko izglītību, kas dzīvo Rīgā un citās Latvijas pilsētās. Laukos vides problēmas tiek uzskatītas par mazāk savarīgām, ko varētu skaidrot gan ar labāku apkārtējās vides kvalitāti, gan ar citiem faktoriem, piemēram, ārkārtīgi zemo labklājības līmeni, kas nomāc rūpes par visu pārējo (sk. PD P8, 3.2. nodaļu). Savukārt tādi faktori kā dzimums, vecums, tautība un reǵions, kurā dzīvo respondents, viedokli par apkārtējās vides problēmām neietekmē.

Izvērtējot iedzīvotāju viedokli, ka vides aizsardzībai ir jābūt prioritātei, pat ja tas nozīmē lēnāku ekonomisko izaugsmi un zināma skaita darbavietu zaudēšanu, un viedokli, ka ekonomiskajai izaugsmei un darbavietu radīšanai ir jābūt prioritātei, pat ja tādēl zināmā mērā cieš vide, jāsecina, ka vērtējumu par šiem diviem spriedumiem ietekmēja vairāki demogrāfiskie faktori: dzimums, tautība un iedzīvotāju dzīvesvieta, taču neietekmēja iedzīvotāju vecums, izglītîba un reǵions. Vīrieši (69,0\%) biežāk nekā nekā sievietes $(51,8 \%)$ uzskata, ka ekonomikas izaugsmei ir jābūt prioritātei, pat ja tādēl cieš daba. Tāpat latviešiem biežāk nekā cittautiešiem vairāk rūp dabas aizsardzība nekā ekonomikas izaugsme un darbavietu radīšana (sk. PD P8 3.2. nodaļu).

\subsection{Ekologiisko risku identificēšana un novērtējums}

Viens no ekologiskās apziņas komponentiem ir cilvēku norūpētība par vides degradāciju un tās novēršanu. U. Beks norāda, ka liela daḷa modernās 
sabiedrības risku ir t.s. luksusa riski, kas saistās ar dzives apstākḷu uzlabošanas iespējamām sekām, nevis cīṇu ar dabas spēkiem vai rūpēm par izdzīvošanu. U. Beks aprāda šādas risku sekas riska sabiedrībā: 1) delokalizācija; 2) neaprēķināmība; 3) nesabalansētība (Beks, 2006: 234).

Šajā nodaļā atsevišķi pētnieciskie jautājumi tika formulēti tā, lai izvērtētu, kā Latvijas iedzīvotāji identificē un definē ekoloǵiskos riskus, novērtē dabas un tautsaimniecības procesus, kas rada ekoloǵiskos riskus, kā arī kaitējumu, ko rada ekoloǵiskie riski, tādējādi izvērtējot iedzīvotāju norūpētîbu par vides degradāciju, kas ir viens no ekologiskās apziņas rādītājiem.

Uz jautājumu, vai vinuu dzive ir pakḷauta ekologiskiem riskiem, 42,8\% respondentu atbildēja apstiprinoši, 40,0\% respondentu atbildēja noliedzoši, bet 17,3\% respondentu bija grūti formulēt viedokli (bāze n=813) (sk. grafisko attēlu P6 E.1).

Raksturojot ekologisko risku, ${ }^{5}$ respondentu atbildēs pārliecinoši dominēja viedoklis, kas atbilst riska sabiedrības teorētiķu raksturojošai pazīmei - 67,3\% norāda, ka ar ekoloǵisko risku saistās cilvēka darbības rezultāts jeb apkārtējās vides piesārņojums. Šajā atbilžu kopā iedzīvotāji visbiežāk atzīmējuši gaisa un ūdens piesārņojumu.

Kā nākamo lielāko ekoloǵisko risku respondenti (17,0\%) norāda dažādas dabas problèmas, no kurām dạ̧a ir dabas nelaimes, bet daļu var raksturot kā cilvēka darbības radītās sekas. Nedaudz mazāk respondentu norāda šādus ekoloǵiskos riskus (vai šī riska sekas): ekologisko problēmu ietekme uz cilvēku veselību, pārtikas problēmas, bažas par dažādām katastrofām, avārijām, dažādu ķimikāliju lietošanu, citas ar rūpniecību saistītas problēmas, kūlas dedzināšanu un mežu izciršanu. Daļa respondentu riska jēdzienā iekḷāva atbildes, kas skar vispārīgu attieksmi pret riskiem, daḷai respondentu jēdziens

5 Tiem respondentiem, kuri norādīja, ka viṇu dzīve ir pakḷauta riskiem, tika lūgts precizēt, ko viņi saprot ar vārdiem ,ekoloǵiskais risks”, respondentiem tika piedāvāta iespēja sniegt trīs atbilžu variantus. 
„ekoloǵiskie riski” saistījās ar dažādiem ierobežojumiem, ko izraisa ekologiiskās situācijas pasliktināšanās. Salīdzoši maz respondentu (2,9\%) kā ekoloǵisko risku nosauca klimata pārmaiņas, pamatā tika sniegta vispārīga atbilde „klimata izmaiņas, siltumnīcas efekts, globālā sasilšana”.

Iedzīvotāju vērtējumā trīs bīstamākie tautsaimniecības procesi, kas g̊enerē ekoloǵiskos riskus, ir atkritumu izgāšana mežā, nekontrolēts ķimikāliju lietojums lauksaimniecībā un pārtikas rūpniecībā, kā arī ūdenstilpju piesārņojums. Vismazāk bīstami ekoloǵisko risku ǵenerēšanas aspektā ir mazo HES būvniecība un to darbības tehnologiskie procesi (sk. PD P6 E.3. att.).

Pārbaudē ar $\chi^{2}$ testu, lai noskaidrotu, kā sniegtās atbildes, kas raksturo Latvijas iedzìvotāju viedokli par ekoloǵisko risku saturu, ietekmē sociāldemogrāfiskie faktori, šāda saistība tika konstatēta starp diviem dažādiem mainīgajiem. Izrādījās, ka iedzīvotāju uzskatu neietekmē dzimums, izglītība un tautība, savukārt ietekmē vecums, reǵions un dzīvesvieta.

To respondentu, kuri uzskata, ka viṇi ir pakḷauti ekolog̣iskajiem riskiem, procentuāli visvairāk ir Rīgā. Tas nepārsteidz, jo Rīgā ir liela iedzīvotāju koncentrācija, attiecīgi liels automašīnu skaits, daudz atkritumu u.tml. Vecuma grupu griezumā tie, kuri uzskata, ka ir pakḷauti ekoloǵiskajiem riskiem, lielākoties pieder vecumgrupai 35-44 g.v. un 25-34 g.v. Bet vismazāk par ekoloǵisko risku draudiem satraucas cilvēki vecumā no 18 līdz 24 gadiem un no 55 līdz 74 gadiem. Vispārinot varētu teikt, ka tas vismazāk satrauc ,jaunos cilvēkus” un „vecākos cilvēkus” (sk. PD P8 3.3. nodaļu).

\subsection{Iedzīvotāju viedoklis par riska sabiedrību}

Par riska sabiedrību raksturojošu pazīmi tiek uzskatīta arī informācijas pārpilnība par iespējamiem riskiem, turklāt pretēji industriālajai sabiedrībai, kur riskus definēja eksperti un autoritātes, riska sabiedrībā iedzīvotāju uzticēšanās ekspertu sistēmām ir mazinājusies vai pat izzudusi pavisam. Vienlaikus risku 
sekas to sarežǵgitīibas un iespējamo nākotnes seku dēḷ nav iespējams ne prognozēt, ne arī pret tiem pietiekami nodrošināties, kā tas bija iepriekšs, turklāt informācijas pārbagātība jautājumā par riskiem rada jaunus riskus.

Šajā nodạ̦ā pētnieciskie jautājumi tika formulēti tā, lai varētu izvērtēt to, vai Latvijas iedzīvotāju viedokḷi ir salīdzināmi ar šīm riska sabiedrību definējošām pazīmēm, un to, kādi sociāldemogrāfiskie faktori ietekmē atbildes.

Latvijas respondentu sniegtās atbildes apstiprina ar̄i riska sabiedrības teorētiķu atziņu, ka sabiedrība ikdienā saņem tik daudz informācijas par dažādiem riskiem, ka tajā grūti orientēties, savukārt risku neprognozējamās sekas zināmā mērā liedz strukturēt rīcības modeli to novēršanai, jo nav pieejamas ticamas zināšanas par riska raksturu.

Respondentiem tika vaicāts, vai viņi piekrīt apgalvojumam, ka jebkura dz̄̄ves sfēra ir pakḷauta zināmiem draudiem jeb riskiem. Latvijas iedzīvotāji apzinās dzīvi saistībā ar zināmiem, riskiem: 66,3\% aptaujāto atbildēja apstiprinoši, ka ikdienas dzīvē jebkura sfēra ir pakḷauta zināmiem riskiem, $18,5 \%$ to noliedza, bet lielai daļai respondentu $(15,2 \%)$ nebijaviedokḷa par šo jautājumu (sk. PD P6 R.1. att.). No visiem respondentiem, kuri uz jautājumu „Vai piekrītat apgalvojumam, ka jebkura dzīves sfēra ir pakḷauta zināmiem draudiem jeb riskiem?" atbildēja apstiprinoši (n=539), 88,3\% minēja konkrētus riskus. Savukārt no respondentiem, kas minēja konkrētus riskus ( $\mathrm{n}=476), 61,9 \%$ nosauca ekologiska rakstura iemeslus (sk. PD P6 R.2.a., R.2.b. att.).

$78,3 \%$ respondentu uzskata, ka iespējamo riska kaitējumu var prognozēt tikai aptuveni, 71,1\% -, ka riska bīstamības pakāpi nosaka dažādu jomu eksperti, un gandrīz tikpat daudz aptaujāto (71,3\%) piekrīt viedoklim, ka sabiedrības bezdarbība rada jaunus riskus (sk. PD P6 R.3. att.).

Nedaudz vairāk kā puse Latvijas iedzīvotāju uzskata: lai gan viņi apzinās ekoloǵisko risku pastāvēšanu, tomēr domā, ka viņu eksistence nav apdraudēta $(55,5 \%) ; 52,9 \%$ respondentu atzīst, ka par katastrofām, avārijām un riskiem, kas saistīti ar ekologiju, runā tik daudz, ka nav iespējams par to ik dienu 
uztraukties. Aptuveni pusei izdzīvotāju (48,9\%) ir šāds viedoklis: jo vairāk informācijas par riskiem viņi saņem, jo rodas lielāka pārliecība par risku nepārtrauktu pieaugumu. Tajā pašā laikā tikai 25,4\% aptaujāto uzskata, ka informācijas pārpiln̄̄ba par ekoloǵiskajiem riskiem ǵenerē jaunus riskus.

Uzdodot jautājumu par to, vai ekologiskas avārijas gadījumā respondenti spētu sevi pasargāt, tikai $24,2 \%$ aptaujāto atbildēja apstiprinoši, bet $59,2 \%$ aptaujāto uzskatīija, ka viniiem tas neizdotos.

Ar $\chi^{2}$ testu statistiski pārbaudot, kā sociāldemogrāfiskie faktori ietekmē Latvijas iedzīvotāju atbildes, kas raksturo vinuu sniegto vērtējumu attiecībā uz pazīmēm, kas piemīt riska sabiedrībai, jāsecina, ka iedzīvotāju apgalvojumu par to, vai viņi piekrīt atziņai, ka jebkura dzīves sfēra ir pakḷauta zināmiem draudiem jeb riskiem, ietekmēja tādi mainīgie kā vecums, izglītība, reǵions un arī dzīvesvieta. Lai gan visi respondenti diezgan vienprātīgi uzskata, ka jebkura dz̄ives joma ir pakḷauta riskiem, tomēr, spriežot par riskiem kopumā, tieši respondenti ar augstāko izglītību visbiežāk uzskata, ka jebkura dzīves joma ir

pakḷauta riskiem (tā domā arī respondenti, kuri dzīvo Rīgā un Pierīgā), turpretī respondenti ar pamatizglītību visretāk pauž uzskatu, ka riskiem pakḷauta jebkura dzīves joma (sk. PD P.8. 3.4. nodaļu). Tas nozīmē, ka izglītība (un arī reǵions) ir viens no noteicošajiem faktoriem šajā jautājumā.

Savukārt netika konstatēts, ka mainīgajiem dzimums un tautība būtu bijusi ietekme uz iedzīvotāju izteiktajiem apgalvojumu vērtējumiem.

\subsection{Latvijas iedzīvotāju informētība par ekoloğiskajiem riskiem}

Riska sabiedrības teorētiķi, raksturojot riska sabiedrību, norāda, ka šajā sabiedrībā iedzīvotāji ikdienā ir pārsātināti ar informāciju par riskiem, un pati šī situācija rada aizvien jaunu apdraudējuma sajūtu. Savukārt viens no ekoloǵiskās apziņas komponetiem ir iedzīvotāju zināšanas par vidi degradē- 
jošiem faktoriem un to novēršanu. Šì promocijas darba sadaļa ir veltīta tam, lai noskaidrotu iedzīvotāju zināšanas jeb informētību par ekoloǵiskajiem riskiem.

Atbildot uz jautājumu, cik lielā mērā respondenti ir informēti par ekologiskajiem riskiem, kurus varētu radīt apkārtējās vides problēmas, mazāk nekā puse (44,0\%) savu informētības līmeni spēja novērtēt kā labu un ļoti labu. Saņemtās atbildes arī liecina, ka Latvijas sabiedrība kopumā nav informēta par rīcības plāniem paaugstinātas bīstamības gadījumos, jo lielākā daļa respondentu atzina, ka nezinātu, kā rīkoties rūpnieciskas avārijas vai tās draudu gadījumos paaugstināta riska objektos, ind̄̄gu ķīmisko vielu noplūdes un atomreaktora avārijas gadījumā. Jāsecina, ka Latvijas iedzīvotāji kopumā nav gatavi ārkārtas situācijām un ir nepietiekami informēti par šāda veida avārijām un pareizāko rīcību to gadījumā (sk. PD P.6.C.2., C.3, C.4.).

Iemesls iedzīvotāju sliktajai informētībai par rīcību dažādu tehnogēno avāriju gadījumos, var būt viņu pārliecība, ka šādas avārijas nevar skart Latviju un tās iedzīvotājus, tāpēc informācija par tām nav nepieciešama. Tas atspoguḷojas arī iepriekš respondentiem uzdotajā jautājumā par to, kāda šobrīd ir situācija Latvijā un vai Latvijas iedzīvotāji ir pakḷauti ekologiskajiem riskiem. 62,5\% respondentu atbildēja, ka Latvijas iedzīvotāji ir pakḷauti salīdzinoši nedaudziem ekoloǵiskajiem riskiem, bet 18,8\% - ka Latvijā iedzīvotāji praktiski nav pakḷauti ekologiiskajiem riskiem.

Salīdzinot populārāko informācijas avotu sadalījumu pēc tā, no kurienes respondenti saņem informāciju par ekoloǵiskajiem riskiem un no kurienes viņi labprātāk vēlētos to saņemt, var secināt, ka nenoliedzami līderi informācijas izplatīšanā ir televīzija, internets, prese un radio.

Ar U. Beka atziṇu, ka riska sabiedrībā eksperti ir tie, kas nosaka riska pakāpi un bīstamību, sabalsojas fakts, ka 18,7\% respondentu ir nosaukuši ekspertu sniegto vērtējumu par labāko vēlamo informācijas ieguves avotu, tādējādi atklājot vēlmi saņemt izzinošu un kvalitatīvu informāciju par 
ekoloǵiskajiem riskiem. Tomēr pašlaik ekspertu sniegto informāciju kā avotu zināšanām par ekoloǵiskajiem riskiem norāda tikai 4,8\% respondentu.

Veicot pārbaudi ar $\chi^{2}$ testa palīdzību, hipotētiskajam pieņēmumam ,pastāv statistiski būtiska saistība starp iedzīvotāju informētības līmeni un viedokli, ka informācijas pārpiln̄̄ba par ekoloǵiskajiem riskiem rada jaunus riskus”, var noskaidrot, ka respondenti, kuri ir labi informēti par ekoloǵiskajiem riskiem, arī biežāk nekā citi respondenti uzskata, ka informācijas pārpilnība par ekoloǵiskajiem riskiem rada jaunus riskus (sk. PD P.7. 3.16. tabulu).

$\operatorname{Ar} \chi^{2}$ testa palīdzību pārbaudot, kā sociāldemogrāfiskie faktori ietekmē sniegtās atbildes, kas raksturo Latvijas iedzīvotāju viedokli par ekologisko risku saturu, tika konstatēts, ka atbildes uz jautājumu, cik lielā mērā iedzīvotāji kopumā ir informēti par tiem ekologiskajiem riskiem Latvijā, kurus varētu radīt apkārtējās vides problēmas, - ietekmēja un ir savstarpēji atkarīgi tādi mainīgie kā respondentu vecums, izglītība un reǵions, taču neietekmēja dzimuma, tautības vai dzīvesvietas faktori. Piemēram, izglītības līmenis nosaka respondentu informētību par ekoloǵiskajiem riskiem, jo respondenti ar pamatizglîtīibu jūtas vismazāk informēti par ekologiskajiem riskiem (sk. PD P.8., 3.5. nodalı).

\subsection{Latvijas iedzīvotāju gatavība darboties ekolog̣isko risku mazināšanā}

Ekologisko apziņu raksturo arī iedzīvotāju gatavība ziedot laiku un ieguldīt līdzekḷus vides uzturēšanā un aizsardzībā. Šajā nodạ̦ā pētnieciskie jautājumi tika formulēti tādējādi, lai izvērtētu, vai pastāv statistiski būtiska saistība starp Latvijas iedzīvotāju vides uzlabošanas aktivitātēm laika dimensijā, un noskaidrotu, kādas ir konkrētās aktivitātes vides situācijas uzlabošanā, kurās gatavi iesaistīties iedzīvotāji. 
Vairums respondentu atbildēja, ka nākotnē iesaistītos šādās aktivitātēs: izmetīs atkritumus tikai tiem paredzētās vietās (noteikti - 59,1\%, drīzāk jā 31,7\%), lietos ekonomiskās spuldzītes (noteikti - 45,6\%, drīzāk jā - 38,3\%), nodos novecojušo sadzīves tehniku, baterijas tikai šādam nolūkam paredzētajās vietās (noteikti - 41,4\%, drīzāk jā - 40,6\%), šķiros sadzīves atkritumus (noteikti - 36,3\%, drīzāk jā - 43,1\%), lietos videi draudzīgākus sadzīves ķīmiskos līdzekḷus (noteikti - 33,9\%, drīzāk jā - 44,9\%) u.c.

Veicot pārbaudi ar $\chi^{2}$ testa palīdzību, lai noskaidrotu, vai pastāv statistiski būtiska saistība Latvijas iedzīvotāju aktivitātēs vides aizsardzības jomā laika dimensijā, apstiprinājās statistiski būtiska saistība starp šiem mainīgajiem. Visas veiktās darbības šobrīd ir aktīvākas, nekā tas ir bijis pagātnē (izṇemot sezonas aktivitātes - koku stādī̌sana, dalība talkās un pārvietošanās ar velosipēdu). Var secināt, ka aktivitātēm, kas fiksētas šĩ jautājuma ietvaros, ir tendence palielināties: piemēram, 29,4\% respondentu apgalvo, ka pagātnē ir škirojuši sadzīves atkritumus, bet šobrīd to dara jau 35,9\%, savukārt nākotnē to ir nolēmuši darīt 79,4\% atbildējušo (3.6. att.).

$\operatorname{Ar} \chi^{2}$ testa palīdzību pārbaudot, kā sociāldemogrāfiskie faktori ietekmē sniegtās atbildes, kas raksturo Latvijas iedzīvotāju gatavību piedalīties dažādās aktivitātes, lai uzlabotu vides situāciju, tika konstatēts, ka ne visi sociāldemogrāfiskie faktori ir atkarīgi no mainīgā, kas apzīmē gatavību rīkoties.

Runājot kopumā par dalību aktivitātēs, kas varētu uzlabot vides situāciju, visos gadījumos, izņemot ūdens attīrīšanas ierīču iegādi pie privātmājām, sievietes ir gatavas piedalīties dažādās aktivitātēs biežāk nekā vīrieši, tāpat visos gadījumos aktīvāki solās būt latvieši nekā cittautieši, un arī respondenti ar augstāko izglītību ir gatavi būt aktīvāki gandrīz visās jomās cilvēki ar pamata un vidējo izglītību (sk. PD P8 3.6. nodaļu).

Aplūkojot dažādus rādītājus, kas raksturo iedzīvotāju zināšanas un rūpes par ekologiskajām vērtībām, jāsecina, ka visbiežāk tie ir savstarpēji atkarīgi no tādiem demogrāfiskajiem rādītājiem kā vecums un izglìtība, savukārt statistiskā 
atkarība visretāk ir konstatējama saistībā ar apdzīvotās vietas tipu, respektīvi, no tā, vai cilvēks dzìvo Rīgā, pilsētā vai laukos, kā arī no tautības. Turklāt aktivitāti raksturojošos main̄̄gos ietekmē gandrīz visi vai visi demogrāfisko rādītāju main̄̄gie. Citu bloku raksturojošo mainīgo atkarība no tik daudziem demogrāfiskajiem rādītājiem nav vērojama.

Veidojot teorētisko modeli (2. att.), jau darba sākumā tika paredzēts pārbaudīt jautājumu moduḷu savstarpējo saistību un ietekmi. Ar Kendall's tau $b$ koeficientu tika pārbaudīta savstarpējā saistība starp (1) ekologisko risku satura vērtējuma moduli un moduli, kas raksturo aktivitāti risku mazināšanā; (2) starp moduli „informētība par ekologiskajiem riskiem” un moduli ,aktivitātes riska mazināšanai”, (3) starp informētības par ekoloǵiskajiem riskiem moduli un ekoloǵisko risku satura vērtējuma moduli. Visos trijos gadījumos starp moduḷiem tika pierādīta savstarpējā saistība. Ar Goodman un Kruskal tau un rangu korelācijas koeficientiem tika pārbaudīta savstarpējā saistība starp moduli "aktivitāte risku mazināšanā” un vispārējās attieksmes moduli, kā arī starp ekologisko risku satura vērtējuma moduli un vispārējās attieksmes moduli. Abos gadījumos savstarpējā saistība tika apstiprināta. Datu analīzes gaitā apstiprinājās moduḷu savstarpējā saistība, tādējādi pierādot izvirzītās hipotēzes.

\section{SECINĀJUMI}

Promocijas darba teorētisko pamatojumu autore balsta uz diviem nozīmīgiem socioloǵijas virzieniem, kuri pievērsušies vides problēmu izpētei, tie ir amerikāṇu V. Katona un R. Danlepa izstrādātā ,jaunā ekologiskāā paradigma" ar vides reālisma ideju atspoguļojumu pētījumos, kas veikti kopš 20. gadsimta 70. gadu beigām, un eiropiešu U. Beka, E. Gidensa, N. Lūmana u. c. „vides konstruktīvisma” pieeja, kas attīstìjās, sākot ar 90. gados publicētiem pētījumiem par riska sabiedrību. 
U. Beks, E. Gidenss, N. Lūmans teorētiskās interpretācijas aspektā ir ļoti atšķirīgi, tomēr autore savā riska sabiedrības konceptualizācijā izmanto tieši šo triju autoru riska „brīvo” definējumu, proti, lai gan katrs no minētajiem teorētiķiem sniedz savu interpretējumu riskam un riska sabiedrībai, tomēr definē to drīzāk ar vairākām pazīmēm, nevis ar vienu teorētiski pamatotu un praktiski apstiprinātu definīciju (N. Lūmana interpretācija ir visnenoteiktākā, savukārt visprecīzāk no š̄s trijotnes risku un riska sabiedrību interpretē U. Beks). Visbeidzot, šajā promocijas darbā autore ir apvienojusi gan riska sabiedrības un ekologisko risku teorētisko aspektu izklāstu, gan iepriekš veikto pētījumu analīzi par ekolog̣isko problemātiku, gan arī izstrādājusi un realizējusi aptauju, kas vērsta tieši uz ekoloǵisko risku vērtējumu, nevis vispārīgo vides jautājumu analīzi.

Analizējot jēdziena risks definīciju un izcelsmi, autore promocijas darba pirmajā nodaḷā pievērsa pastiprinātu uzman̄ibu riska sabiedrības jēdzienam. Riska sabiedrības ietvaros viens no būtiskākiem riskiem, ar ko saskaras mūsdienu sabiedrība, ir ekologiskais risks. Pirmajā nodaļā aplūkoto autoru (galvenokārt N. Lūmans, E. Gidenss, U. Beks) ideju padzilıināta analīze sniedz teorētisko pamatojumu promocijas darbā pētìtajai tēmai par ekoloǵisko risku vērtējumiem kā ekoloǵisko apziņu raksturojošiem elementiem. Papildus aplūkotas arī citu autoru pieejas riska uztveres analīzē, izvērtēti dažādi risku traktēšanas model̦i, lai gūtu padziļinātu ieskatu risku un riska sabiedrības izpētes problemātikā.

Promocijas darba izstrādes gaitā, realizējot šā darba Ievadā izvirzītos uzdevumus, tika sasniegts darba mērḳis un veikta Latvijas sabiedrības ekoloǵiskās apziņas izpēte, pamatojoties uz Latvijas iedzīvotāju priekšstatiem par ekoloǵisko risku vērtējumu, vienlaikus noskaidrojot ekoloǵiskās apziņas komponentu savstarpējo saistību. Darba procesa gaitā autore nonāca pie vairākiem secinājumiem: 
- Riska jēdziens, lai arī tiek līdzīgi teoretizēts dažādās disciplīnās, vēsturiski un katrā konkrētā zinātņu nozarē iegūst nedaudz niansētu skatījumu. Kopīgā iezīme ir tā, ka risks vienmēr saistās ar varbūtības elementu piel̦āvumu kādu kaitīgu seku iestāšanās gadījumam.

- Riska identificēšana un vadīšana katrā sabiedrībā var tikt risināta atšķirīgi, ņemot vērā gan izpratni par risku, gan arī sabiedrības attieksmi pret riska pię̧aujamības apmēriem.

- Pastāv piecas dažādas riska uztveres teorijas: zināšanu, personības, ekonomikas, politikas un kultūras riska uztveres teorija. Proti, interpretējot indivīda riska uztveri, tiek lietoti zināšanu, personības īpatn̄̄bu, ekonomiskā līmeņa, politiskās izvēles un kultūras savdabību kritēji.

- Riska sabiedrības ietvaros viens no būtiskākiem riskiem, ar ko saskaras mūsdienu sabiedrība, ir ekoloǵiskais risks.

- Dabas socializācijas aizsākumu var uzskatīt par pirmsākumu ekoloǵiskajai atsvešinātībai, ko U. Beks savā riska sabiedrības koncepcijā uzskata par vienu no riska sabiedrības raksturojošām pazīmēm. Proti, dabas socializācija ir sekmējusi dominējošās sociālās paradigmas formēšanos, kuras pamatā bija cilvēka dominance pār dabu, bet dabas būtiskākā funkcija - labumu ražošana cilvēcei un dabas resursu neizsmel̦amība.

- Iedzīvotāji, lai arī ir informēti par ekoloǵiskajiem riskiem, tomēr neapzinās, ka dzīvo riska sabiedrībā, jeb, izsakoties U. Beka vārdiem, sabiedrību nav iespējams pasargāt no jaunu risku ražošanas, jo sabiedrībā, kas nevēlas ievērot un apzināties esošos riskus, nav iespējams tos mazināt arī nākotnē.

- Starptautiskie pētījumi apkārtējās vides jomā netiek veikti pietiekami bieži, un Latvija, iespējams, neizmanto visas iespējas piedalīties šādos pētījumos un samērā reti iniciē to veikšanu nacionālā līmenī. Līdz šim iegūtā informācija nenodrošina pilnu nepieciešamo ainu plaša mēroga pasākumu, 
programmu izstrādei, kas varētu arvien vairāk veicināt sabiedrības ekologiskās apziņas attīstīšanu.

- Politikas veidotājiem būtu svarīgi ne tikai veicināt ekoloǵiskās apziṇas līmeņa paaugstināšanu, bet arī regulāri novērtēt šo pasākumu efektivitāti - tas ļautu apzināt jautājumus, kuriem nepieciešams pievērst īpašu uzmanību.

- Iepriekš veiktie pētījumi vides aizsardzības jomā pārsvarā tikuši analizēti, neinterpretējot to rezultātus no ekologiskās apziņas aspekta un tajos nav lietots ekoloǵisko risku vērtējums kā instruments ekologiskās apziñas raksturošanai. Tāpēc promocijas darba ietvaros veiktajā empīriskajā pētījumā, autore pievērsa pastiprinātu uzmanību Latvijas iedzīvotāju ekoloǵiskajai apziņai, interpretējot iedzīvotāju ekologiisko risku vērtējumu riska sabiedrības kontekstā.

- Latvijas iedzīvotāji ir norūpējušies par apkārtējās vides stāvokli, dalaiai iedzīvotāju ir pietiekamas zināšanas par vidi degradējošiem faktoriem un iespējām aktīvi rīkoties vides uzlabošanas labā.

- Latvijas iedzīvotāju ekologiiskās apziṇas līmenis veicina gatavību rīkoties apkārtējās vides stāvokḷa uzlabošanai, tomēr cilvēki uzskata, ka šo jautājumu risināšanā liela loma pieder vald̄ibai un ka nodokḷu slogs netiek pietiekami izmantots ekoloǵisko problēmu risināšanai. Pašreizējā sarežğīitā ekonomiskā situācija ir pamats tam, ka par primāriem tiek uzskatīti ekonomiskie un nabadzības izskaušanas jautājumi.

- Latvijas iedzīvotāji kopumā nav informēti par rīcības plānu paaugstinātas bīstamības tehnogēno avāriju vai to draudu gadījumos. Noskaidrojot cēloņus iedzīvotāju sliktajai informētībai par rīcību dažādu tehnogēno avāriju gadījumā, pamatojums tam var būt viṇu pārliecība, ka šādas avārijas nevar skart Latviju un tās iedzīvotājus, tāpēc informācija par tām nav nepieciešama. Šāda attieksme rada zināmas bažas, ka Latvijas sabiedrība savlaicīgi neapzinās jaunus riska veidus, kas, kā uzsvēra U. Beks, 
modernizācijas ietekmē formējas riska sabiedrībā. Jāatzīmē arī pozitīvā tendence: vairums respondentu uzskata, ka zina, kur, ja vajadzēs, var atrast informāciju par nepieciešamo ekoloğisko risku.

- Iedzīvotāji, kuri atzīst, ka nav pietiekami informēti par ekologiskajiem riskiem, bet tomēr nepieciešamības gadījumā cenšas iegūt papildu uzziņu par viņus interesējošu ekologisko risku un tā radīto kaitējumu, ir tā potenciālā Latvijas iedzīvotāju daļa, kas tendēta identificēt un apzināties ekologiskos riskus. Šie iedzīvotāji ir pasīvi, bet, ja viņiem tiktu sniegta bezmaksas informācija par dažādiem ekoloǵiskajiem riskiem un procesiem, kas šos riskus izraisa, tad aktivitāte, iespējams, palielinātos un ekoloǵisko risku radītais kaitējums tiktu mazināts.

- Iedzīvotāju apzināšanās, ka viṇu personiskais ieguldījums var būt nozīmīgs vides stāvokḷa uzlabošanā, paaugstina iespēju, ka viṇi aktīvi iesaistīsies reālās vides aizsardzības aktivitātēs. Latvijas iedzīvotāji aizvien vairāk sāk apzināties vides aizsardzības nozīmi un iesaistās ekoloǵisko problēmu apspriešanā un aktīvā rīcībā, kas savukārt ietekmē arī lēmumu pieņemšanu vides politikas jomā valsts līmen̄̄. Iedzīvotāji gatavi vairāk iesaistîties tādās aktivitātēs, kas tieši neskar viṇu ekonomisko situāciju.

- Latvijas iedzīvotāji ir gatavi mainīt tos ikdienas paradumus, kas veicinātu vides aizsardzību, bet neprasa lielus finansiālus ieguldījumus.

- Aplūkojot dažādu ekoloǵisko vērtību raksturojošos rādītājus kopumā, var secināt, ka visbiežāk tie ir savstarpēji atkarīgi no tādiem sociāldemogrāfiskem rādītājiem kā vecums un izglītība, bet statistiskā atkarība visretāk ir vērojama no apdzīvotās vietas tipa (tas, vai cilvēks dzīvo Rīgā, pilsētā vai laukos) un tautības. Turklāt aktivitāti raksturojošos mainīgos ietekmē gandrīz visi vai piln̄̄gi visi demogrāfisko rādītāju mainīgie. Citu bloku raksturojošo main̄̄go mijatkarīga saiste ar tik daudziem demogrāfiskajiem rādītājiem nav novērojama. 
Veicot savstarpējo sakarību pārbaudi ar Kendall's tau b koeficientu, tika pārbaudītas promocijas darba sākumā izvirzītās hipotēzes. Visos trijos gadījumos tika pierādīta savstarpējā saistība starp moduḷiem.

(1) Latvijas iedzīvotāju ekoloǵisko risku satura vērtējumam ir vāja savstarpēja saiste ar Latvijas iedzīvotāju aktivitāti risku mazināšanā, proti, pastāv mijietekme starp ekoloǵiskās apziņas diviem komponentiem - jo lielāka ir Latvijas iedzīvotāju norūpētība par vides degradāciju, jo lielāka ir gatavība ieguldīt laiku un līdzekḷus vides uzturēšanā. Šī hipotēze sasaucas ar E. O. Sallivana un M. Teilores tēzi par to, ka ekologiskāā apziņa ir atbildes reakcija uz ekoloǵiskām problēmām. Norūpētība par vides degradāciju ir sava veida sociālais katalizators Latvijas iedzīvotāju aktīvākai darbībai vides aizsardzībā, liekot lietā personiskos līdzekḷus un laiku.

(2) Latvijas iedzīvotāju informētībai par ekolog̣iskajiem riskiem ir vāja savstarpēja saiste ar ekoloǵisko risku satura vērtējumu, proti, tikai 6 indikatori no 20 iespējamiem norāda uz savstarpējo ietekmi. Tātad pastāv vāja saistība starp zināšanām par vidi degradējošiem faktoriem un norūpētību par vides degradāciju. Šì hipotēze sasaucas ar U. Beka tēzi par risku leǵitimāciju: sabiedrība zina, ir informēta, ka riski pastāv, bet izvēlas uzvedību, kas liecina, ka tā šo informāciju par risku esamību noliedz vai ignorē. Respektīvi, zināšanas par ekologiskajiem riskiem neietekmē iedzīvotāju norūpētību par ekoloǵiskām problēmām. Tādējādi ir grūti novērst to, ko sabiedrība noliedz.

(3) Latvijas iedzīvotāju informētībai par ekologiiskajiem riskiem ir vāja savstarpēja saiste ar viņu aktivitāti risku mazināšanā: ja iedzīvotāji jūtas plaši informēti par ekoloǵiskajiem riskiem, tad viṇi aktīvi līdzdarbojas vai ir gatavi piedalīties risku mazināšanā, ieguldot laiku un līdzekḷus. Tomēr līdzdalības vai gatavības piedalīties kontekstā jāņem vērā, ka informētības pieaugums automātiski nenozīmē pareizu rīcību risku mazināšanā, kā to norāda $\mathrm{M}$. Duglasa un $\bar{A}$. Vildavskis un par ko zināmā mērā liecina arī Latvijas iedzīvotāju attieksme jautājumā par tādu līdzdalību, kam būtu ietekme uz 
personisko materiālo labklājīibas līmeni. Līdzīgi kā U. Beks izsakās par iespēju mazināt sabiedrības pakḷautību riskiem tikai tādā gadījumā, ja cilvēki apzinās riskus saturošo situāciju, tāpat var secināt, ka Latvijas sabiedrība, iegūto zināšanu cel̦ā apzinoties iespējamos draudus, arī aktivizējas šo draudu mazināšanai.

Vērtējot Latvijas iedzīvotāju ekologiiskās apziņas struktūru, jāsecina, ka visi trīs ekologiskās apziņas komponenti (norūpētība par vides degradāciju, gatavība ieguldīt laiku un/vai līdzekḷus vides uzturēšanā, zināšanas par vidi degradējošiem faktoriem) lai gan ir savstarpēji vāji saistīti, tomēr šāda saistība pastāv, piemēram, Latvijas iedzīvotāju gatavību ieguldīt laiku un līdzekḷus vides uzturēšanā ietekmē gan zināšanu līmenis par vidi degradējošiem apstākḷiem, gan norūpētība par vides degradāciju; zināšanas par vidi degradējošiem apstākl̦iem ietekmē Latvijas iedzīvotāju norūpētību par vides degradāciju. Ekologiskās apziņas komponentu saturu ietekmē dažādi demogrāfiskie rādītāji, tomēr, raksturojot kopainu, jāsecina, ka visizteiktākās raksturpazīmes ir vērojamas regiionu, dzimumu un izglītības šķērsgriezumā.

Secinājumus, savstarpējās likumsakarības un ietekmējošos faktorus, kas iegūti, analizējot Latvijas iedzīvotāju ekologiisko risku vērtējumu, ir iespējams izmantot kā kritērijus, izstrādājot instrumentāriju Latvijas iedzīvotāju ekologiiskās apziņas komponentu satura veidošanā un ekologiskās apziņas virzības vadīšanā. 


\section{ZINĀTNISKIE RAKSTI PAR PROMOCIJAS DARBA TĒMU}

1. Бришка, И. (2009). Устойчивое развитие: экологические показатели в Латвии. Grām.: Psihologijas, biznesa un sabiedrības sociālās sfêras aktuālās problèmas: teorija un prakse. Rīga: Baltijas Psiholog̣ijas un menedžmenta augstskola, 166.-172. lpp.

2. Briška, I. (2009). Ecological risks in Latvia: Situation dynamics for the period of 2004-2008. In: Economics. Communication Sciences. Political Science. Sociology. Social Policy and Social Work. Law: Collection of Scientific Papers, 2010. Riga: Riga Stradins University, pp. 74-80.

3. Briška, I. (2010). Sustainable development in risk society - ecological situation in Latvia. Journal of Young Scientists (Siauliai University, Lithuania). 1: 265-269.

4. Briška, I. (2010). Społeczeństwo ryzyka: ocena ekologicznego ryzyka na Łotwie. In: Partnerstwo $i$ Wspótpraca a kryzys gospodarczo-społeczny $w$ Europie Środkowej $i$ Wschodniej, tom I. Lublin: Wydawnictwo KUL, s. 650-655.

5. Бришка, И. (2010). Экологические риски: в какой мере мы их осознаем. Mykolas Romeris University, Lithuania.

6. Briška, I., Rungule, R. (2010). Risk society in Latvia: characteristics of environmental aspects. European Integration Studies (Kaunas University of Technology, Lithuania), 4: 22-30.

7. Briska, I. (2010). Sustainable development: dynamics of environmental awareness and environmental behaviour in Latvia, 2006-2010. In: Economics. Communication Sciences. Political Science. Sociology. Social Policy and Social Work. Law: Collection of Scientific Papers, 2011: Rīga Stradiņš University Research Articles. Rīga, pp. 4351.

8. Briška, I. (2011). Awareness of ecological risks: the analysis of internet surveys. In: Społeczeństwo sieci, Gospodarka Sieciowa w Europie Środkowej i Wschodniej, tom 2. Lublin: Wydawnictwo KUL, s. 279-283. 
9. Briška, I., Rungule, R. (2011). Sustainable development: changes in the evaluation of environmental risks in Latvia. Management Theory and Studies for Rural Business and Infrastructure Development (Klaipeda University, Lithuania), 1: 36-43.

10. Briška, I., Rungule, R. (2011). Sustainable development: discourse on environmental values in Latvia. European Integration Studies (Kaunas University of Technology, Lithuania), 5, 7-14.

11. Briška, I. (2013). Ecological risks in the context of sustainable development: statistical indicators in Latvia. European Integration Studies (Kaunas University of Technology, Lithuania).

\section{PUBLICĒTĀS TĒZES}

1. Briška, I. (2009). Awareness of ecological risks: Latvian case. $2^{\text {nd }}$ International scientific conference "Risk Society: Challenges for the 21st Century", p. A3, Griekija, Atēnas, novembris, 2009.

2. Briška, I. (2010). Ilgspējīgā attīstība: ekoloǵisko risku dinamikas vērtējums Latvijā 2004-2008. Rīgas Stradiṇa universitātes 9. zinātniskā konference. Tēzes, 376. lpp., Rīga, marts, 2010.

3. Briška, I, Rungule, R. (2012). Risk society in Latvia: characteristics of environmental aspects. 8th International Scientific Conference "Legal, Political and Economical Initiatives Towards Europe of Knowledge". European Integration Studies, 4: 22, Lietuva, Kauņa, aprīlis, 2010.

4. Briška, I. (2010). Transformation of environmental values discourse: Latvian case study. XVII ISA World Congress of Sociology "Sociology on the Move". Book of Abstracts, p. 216, Gothenburg, Sweden, July, 2010.

5. Briška, I. (2010). Sustainable development: changes in evaluation of ecological risks in Latvia. GIRA 2010 Conference on Corporate Governance, Innovation, Social and Environmental Responsibility. Abstract Book, p. 54, Portugāle, Lisabona, septembris, 2010 .

6. Briška, I. (2010). Ecological risks dynamics: Latvian case. 3. starptautiskā starpdisciplinārā zinātniskā konference "Society, Health, Welfare”, Rīgas Stradiṇa universitāte. Abstracts, p. 28, Rīga, Latvija, novembris, 2010. 
7. Briška, I. (2011). Ecological risks - are we aware of them: research analysis. Rīgas Stradiņa universitātes 10. zinātniskā konference. Tēzes, 420. lpp., Rīga, marts, 2011.

8. Briška, I, Rungule, R. (2011). Sustainable development: discourse on environmental values in Latvia. 9. starptautiskā zinātniskā konference "Legal, Political and Economical Initiatives Towards Europe of Knowledge". European Integration Studies. 5, p. 7, Kauņa, Lietuva, aprīlis, 2011.

9. Briška, I. (2011). Ecological values: changes in the attitudes of the Latvian public. IX Eiropas sociologu konference "Social Relations in Turbulent Times". Abstract Book, p. 269, Ženēva, Šveice, septembris, 2011.

10. Briška, I. (2011). Riska sabiedrība: ekoloǵiskie riski Latvijā. Apvienotais Pasaules latviešu zinātnieku 3. kongress, sekcijas "Vides kvalitāte Latvijā: esošais stāvoklis, izaicinājumi, risinājumi”. Referātu kopsavilkumu krājums, 29. lpp., Rīga, Latvija, oktobris, 2011.

11. Briška, I. (2012). Informētība un ekologisko risku apzināšanās Latvijā: jauniešu viedoklis. Starptautiskā konference „Jaunatne Latvijāa, Eiropā, pasaulē: iespējas un riski”. Tēzes, 28. lpp., Rīga, jūnijs, 2012.

12. Briška, I. Role of information and cognition of environmental risks in Latvia. 4. starptautiskā starpdisciplinārā zinātniskā konference "Society, health, welfare", Rīgas Stradiṇa universitāte, Abstracts, p. 25, Rīga, Latvija, novembris, 2010.

\section{UZSTĀŠANĀS KONFERENCĒS}

1. Baltic International Academy and Higher School of Psychology 2nd International scientific and practical conference "Prospects and Possibilities of Psychology, Business and Social Work in Modern Europe", Rīga, 2009, June, referāts „Долгосрочное развитие: экологические показатели в Латвии”.

2. $2^{\text {nd }}$ International veterinary laboratory scientific and applied conference "Laboratory Diagnostics Today and Its Future Challenges", Latvija, Rīga, augusts, 2009, referāts „Particularities of Research Methodology in Researches on Population Health Issues”.

3. $2^{\text {nd }}$ International scientific conference "Risk Society: Challenges for the $21 \mathrm{st}$ Century”, Grieķija, Atēnas, novembris, 2009, referāts „Awareness of Ecological Risks. Latvian Case". 
4. $9^{\text {th }}$ Ernestas Galvanauskas International scientific conference "Economics and Management: Current Issues and Perspectives”, Lietuva, $\square$ Šaul̦i, novembris, 2009, referāts „Risk Society: Assessment of Ecological Risks in Latvia”.

5. Rīgas Stradiņa universitātes 9. zinātniskā konference, Rīga, marts, 2010, referāts „Ilgspējīgā attīstība: ekoloǵisko risku dinamikas vērtējums Latvijā 2004-2008”.

6. Daugavpils Universitātes 52. starptautiskā zinātniskā konference, Daugavpils, aprīlis, 2010, referāts „Ekologiskie riski - vai mēs tos apzināmies?”.

7. International young scientists conference, Lietuva, $\square$ Šaul̦i, aprīlis, 2010, referāts „Sustainable Development in Risk Society - Ecological Situation in Latvia”.

8. Liepājas Universitātes 13. starptautiskā zinātniskā konference "Sabiedrība un kultūra: Haoss un harmonija”, Liepāja, aprīlis, 2010, referāts „Ekologisko risku apzināšanās Latvijā’".

9. $11^{\text {th }}$ International scientific conference "Partnerstwo $i$ Współpraca a kryzys gospodarczo-społeczny w Europie Środkowej i Wschodniej”, Polija, Nalenčova, maijs, 2010, referāts „Устойчивое развитие: динамика экологических рисков в Латвии”.

10. International scientific conference „Human Potential Development: Search for Opportunities in the New EU States”, Lietuva, Vil̦na, 2010, referāts „Экологические риски: в какой мере мы их осознаем?”

11. XVII ISA World congress of sociology "Sociology on the Move", Gothenburg, Sweden, July, 2010, referāts „Transformation of Environmental Values Discourse: Latvian Case Study". In print.

12. GIRA 2010 Conference on Corporate Governance, Innovation, Social and Environmental Responsibility, Portugāle, Lisabona, septembris, 2010, referāts „Sustainable Development: Changes in the Evaluation of Environmental Risks in Latvia.

13. 3. starptautiskā starpdisciplinārā zinātniskā konference "Society, Health, Welfare", Rīgas Stradiṇa universitāte, Rīga, Latvija, novembris, 2010, referāts „Ecological Risks Dynamics. Latvian Case.

14. Rīgas Stradiṇa universitātes 10. zinātniskā konferencē, Rīga, marts, 2011, referāts „Ekologiskie riski - vai mēs tos apzināmies? Pētījumu analīze”. 
15. 9. starptautiskā zinātniskā konference "Legal, Political and Economical Initiatives Towards Europe of Knowledge”, Lietuva, Kauņa, aprīlis, 2011, referāts „Sustainable Development: Discourse on Environmental Values in Latvia.

16. Starptautiskā zinātniski praktiskā konference „Economical-managerial Aspects of Sustainable Development in Regions and Organizations", Klaipēda, Lietuva, aprīlis, 2011, referāts „Sustainable Development: Changes in the Evaluation of Environmental Risks in Latvia”.

17. Liepājas Universitātes 14. starptautiskā zinātniskā konference "Sabiedrība un kultūra: Haoss un harmonija”, Liepāja, 2011, maijs, referāts „Iedzīvotāju informētība par vides aizsardzību: pētījuma analīze”.

18. IX Eiropas sociologu konference "Social Relations in Turbulent Times”, Ženēva, Šveice, septembris, 2011, referāts „Ecological Values: Changes in the Attitudes of the Latvian Public". 


\section{LITERATŪRAS SARAKSTS}

1. Acton, C., Miller, R. (2009) SPSS for Social Scientistists. New York: Palgrave Macmillan.

2. Ajzen, I. (1989). Attitudes, traits and actions: dispositional predictions of behaviour. In: Berkowitz L. Advances in Experimental Social Psychology. New York: Academic Press, pp. 1-63.

3. Albrecht, S. L. (1975). The Environment as a Social Problem. Ed. by A. L. Mauss. Philadelphia: J. P. Lippincott.

4. Beck, U. (1992a). From industrial society to the risk society. Theory, Culture and Society, 9 (1): 97-123.

5. Beck, U. (1992b). Risk Society. Toward a New Modernity. London: Sage.

6. Beck, U. (1995a). Ecological Enlightenment: Essays on the Politics of the Risk Society. New Jersey: Humanities Press.

7. Beck, U. (1995b). Ecological Politics in an Age of Risk. Cambridge, UK; Malden, MA: Polity Press (repr. 2002).

8. Beck, U. (1999). World Risk Society. Cambridge, UK; Malden, MA: Polity Press.

9. Beck, U. (2002). The terrorist threat: world risk society revisited. Theory, Culture \& Society, 19 (4): 39-55. DOI: 10.1177/0263276402019004003. Pieejams arī: http://tcs.sagepub.com/cgi/content/abstract/19/4/39 (aplūk. 2012.20.V).

10. Beck, U. (2006). Living in the world risk society: A Hobhouse Memorial Public Lecture given on Wednesday 15 February 2006 at the London School of Economics. Economy and Society, 35 (3): 329-345. Pieejams arī: http://hudson2.skidmore.edu/ rscarce/Soc-Th-Env/Env\%20Theory\%20PDFs/Beck-WorldRisk.pdf (aplūk. 2012.20.V).

11. Blok, A., Jensen, M. (2008). Pesticides in the risk society: the view from everyday life. Current Sociology, 56 (5): 757-778.

12. Capra, F. (2003). The Hidden Connections: A Science for Sustainable Living. London: Flamingo.

13. Catton, W. R., Dunlap R. E. (1980). A new ecological paradigm for post-exuberant society. American Behavioral Scientist, 24 (1): 15-47.

14. Christopher, M. (1999). An exploration of the "reflex" in reflexive modernity, the rational and prerational social causes of the affinity for ecological consciousness. Organization Environment, 12 (4): 357-400 DOI: 10.1177/1086026699124001

15. Connolly, J., Prothero, A. (2008). Green consumption: life-politics, risk and contradictions. Journal of Consumer Culture, 8 (1): 117-145. DOI:

10.1177/1469540507086422. Pieejams arī: http://joc.sagepub.com/cgi/content/abstract/8/1/117 (aplūk. 2012.15.III). 
16. Cotgrove, S. (1982). Catastrophe or Cornucopia: The Environment, Politics and the Future. Chichester: John Wiley and Sons.

17. Dalton, R. (1994). The Green Rainbow: Environmental Groups in Western Europe. New Haven, CT: Yale University Press.

18. Douglas, M., Wildavsky, A. (1982). Risk and Culture: An Essay on Selection of Technological and Environmental Dangers. Berkeley: University of California Press.

19. Dunlap, R., Van Liere, K. (1978). New environmental paradigm: a proposed measuring instrument and preliminary results. Journal of Environmental Education, 9: 10-19.

20. Ekberg, M. (2007). The parameters of the risk society: a review and exploration. Current Sociology, 55 (3): 343-366. DOI: 10.1177/0011392107076080. Pieejams arī: http://csi.sagepub.com/cgi/content/abstract/55/3/343 (aplūk. 2012.15.III).

21. Giddens, A. (1990). The Consequences of Modernity. Stanford, CA.

22. Giddens, A. (1991). Fate, risk and security. In: Giddens, A. Modernity and Selfidentity: Self and Society in the Late Modern Age. Cambridge: Polity Press, pp. 109-143.

23. Giddens, A. (1994). Living in a Post-Traditional Society. In: Beck, U., Giddens, A., Lash S. Reflexive Modernization. Politics, Tradition and Aesthetics in the Modern Social Order. Stanford, CA: Stanford University Press, pp. 56-109.

24. Giddens, A. (1996). In Defence of Sociology: Essays, Interpretations, and Rejoinders. Oxford: Polity Press.

25. Gillham, P.F. (2008). Partitipation in the environmental movement. International Sociology, 23(1): 67-83.

26. Hammer, W. (1980). Product Safely Management and Engineering. Englewood Cliffs, NJ: Prentice-Hall.

27. Handler, P. (1979). Some comments on risk. In: 1979 - Current Issues and Studies. Washington, D. C.: The National Research Council, National Academy of Sciences, pp. 3-24.

28. Hadler, M., Haller, M. (2011). Global activism and nationally driven recycling: the influence of world society and national contexts on public and private environmental behavior. International Sociology, 26(3): 315-345.

29. Hägerstrand, T. (1985). Time and culture. In: Kirsch G. et al. (eds.). Time Preferences. Berlin: Wissenschaftszentrum.

30. Inglehart, R. (1977). The Silent Revolution: Changing Values and Political Styles among Western Publics. Princeton, NJ: Princeton University Press.

31. Kalniņa, A., Meņšikovs, V. (2003). Cilvēkdrošība Latvijā. Grām.: Latvija: pārskats par tautas attīstību, 2002/2003: Cilvēkdrošība. Rīga: UNDP. Pieejams arī: http://www.un.lv/files/2001/Kalnina.pdf 
32. Kunreuther, H. (1973). Recovery from Natural Disasters: Insurance or Federal Aid? Washington, D. C.: American Enterprise Institute.

33. Leff, H. L. (1978). Experience, Environment, and Human Potentials. New York: Oxford University Press.

34. Luhmann, N. (1993). Risk: A Sociological Theory. New York: Walter de Gruyter.

35. Lupton, D. (1999). Risk. London; New York: Routledge.

36. MacCrimmon, K.R.,Wehrung, D.A. (1988). Taking Risks: The Management of Uncertainty. New York: Free Press.

37. Meņšikovs, V. (1999). Atomenergèetika un cilvēka dzīves apstākļi: (sociologiskais aspekts). Daugavpils Pedagoǵiskā universitāte, Ekonomikas un sociālo zinātṇu katedra. Daugavpils: Saule.

38. Mitchell, R.G. (1983). Mountain Experience: The Psychology and Sociology of Adventure. Chicago: University of Chicago Press.

39. Mol, A. P. J. (2006). From environmental sociologies to environmental sociology?: A comparison of U.S. and European environmental sociology. Organization Environment, 19 (1): 5. DOI: 10.1177/1086026605285643. Pieejams arī: http://oae.sagepub.com/cgi/content/abstract/19/1/5 (aplūk. 2012.20.V).

40. Nelkin, D., Pollack, M. (1982). The Atom Besieged: Antinuclear Movements in France and Germany. Cambridge: MIT Press.

41. Pfeffer I., Klock, D. (1974). Perspectives on Insurance. Englewood Cliffs: Prentice Hall.

42. Rescher, N. (1983). Risk: A Philosophical Introduction to the Theory of Risk Evaluation and Management. Washington, D. C.

43. Roberts J. A., Bacon D. R. (1997). Exploring the Subtle Relationships between Environmental Concern and Ecologically Conscious Consumer Behavior. Journal of Business Research, 40:78-89.

44. Sanchez M. J., Lafuente, R.(2010). Defining and mesuring environmental consciousness, Revista International de Sociologia (RIS), 68(3): 731-755.

45. Schaefer, R. (1978). What Are We Talking about when We Talk about "Risk"? Critical Survey of Risk and Risk Preference Theories. Luxembourg: International Institute for Applied Systems Analysis.

46. Schlossberg, H. (1990). Canadians Are Serious about Their Environment and Ours, Too. Marketing News, 19 ( March): 16.

47. Short, J. F., Jr. (1984). The social fabric of risk: towards the social transformation of risk analysis. American Sociological Review, 49 (Dec.): 711-725.

48. Singleton, W. T., Hovden, J. (eds.). (1987). Risk and Decisions. Chichester: John Wiley \& Sons. 
49. O`Sullivan, E., Taylor, M. M. (2004). Glimpses of an Ecological Consciousness. In: Learning Toward an Ecological Consciousness: Selected Transformative Practices. Ed. by E. O'Sullivan, M. M. Taylor. Palgrave Macmillan, pp. 5-29.

50. TeBrake, W. (1975). Air pollution and fuel crisis in pre-industrial London, 12501650. Technology and Culture, 16 (July): 337-359.

51. Uhl, Ch. (2003). Developing Ecological Consciousness: Paths to a Sustainable Future. Rowman \& Littlefield Publishers, 375 p.

52. Wildavsky, A., Dake, K. (1990). Theories of risk perception:who fiars what and why. Dedalus, Risk,119(4): 41-60.Pieejams arī:

http://geography.ssc.uwo.ca/faculty/baxter/readings/wildavsky_and_dake_Ch13_in _cutter_theories_of_risk_perception.pdf (aplūk. 2012.20.III).

53. Wilkinson, I. (2001b). Social theories of risk perception: at once indispensable and insufficient. Current Sociology, 49 (1): 1-22.

54. Аптон, Г. (1982). Анализ таблиц сопряженности. Москва: Финансы и статистика.

55. Гришаев, В. (2002). Риск и общество. Москва.

56. Крыштановский, А.О. (2006). Анализ социологических данных с помощью пакета SPSS. Издательский дом ГУ-ВШЭ.

57. Луман, Н. (1994). Понятие риска. Thesis, 5: 135-160.

58. Яницкий, О. Н. (2001). Социология риска: ключевыле идеи. Москва.

59. Яценко Н. Е. (1999). Толковый словарь обществоведческих терминов. Санктпетербург: Лань

\section{Internet resources}

60. Latvija. Pārskats par tautas attīstību 2002/2003. Cilvēkdrošība, Pieejams: http://www.petnieciba.lv/materiali/publik/2003_Latvija_Parskats_par_tautas_attisti bu_2002_2003_Cilvekdrosiba.pdf (aplūk. 2012.15.III).

61. Welfare attitudes in a changing Europe: module template with background information, survey questions to be used in ESS Round 4, European Social Survey: http://www.google.lv/url?sa=t\&rct=j\&q=\&esrc=s\&source=web\&cd=1\&ved=0CB4 QFjAA\&url=http $\% 3 \mathrm{~A} \% 2 \mathrm{~F} \% 2 \mathrm{Fwww}$.europeansocialsurvey.org\%2Findex.php $\% 3 \mathrm{~F}$ option\%3Dcom_docman\%26task\%3Ddoc_download\%26gid\%3D632\%26itemid\% 3D80\&ei=UD5rUNP3MYe0tAb934DABw\&usg=AFQjCNE5UAL19uYJWxx8B_5 fD3RPrB3JQA\&sig2=U6L0a0-5MQPv13DGTGzRPg 